OECD Environment Working Papers No. 73

\title{
Greening Household \\ Behaviour and Water
}

\section{Céline Nauges}

https://dx.doi.org/10.1787/5jxrclrr79f7-en 


\section{Unclassified}

ENV/WKP(2014)11

Organisation de Coopération et de Développement Économiques

Organisation for Economic Co-operation and Development

10-Dec-2014

ENVIRONMENT DIRECTORATE

English - Or. English

\section{ENVIRONMENT WORKING PAPER No. 73 - GREENING HOUSEHOLD BEHAVIOUR AND WATER}

By Céline Nauges (1)

(1) The University of Queensland, Australia.

OECD Working Papers should not be reported as representing the official views of the OECD or of its member countries. The opinions expressed and arguments employed are those of the author(s).

Authorised for publication by Simon Upton, Director, Environment Directorate.

JEL Classification: C51, D11, D12, Q25, Q58.

Keywords: Environmental attitudes, labelling, tap water, water-saving behaviour, investment in water-efficient devices, water quality, household survey.

OECD Environment Working Papers are available at www.oecd.org/env/workingpapers.htm

JT03368376

Complete document available on OLIS in its original format

This document and any map included herein are without prejudice to the status of or sovereignty over any territory, to the delimitation of international frontiers and boundaries and to the name of any territory, city or area. 


\section{OECD ENVIRONMENT WORKING PAPERS}

"OECD Working Papers should not be reported as representing the official views of the OECD or of its member countries. The opinions expressed and arguments employed are those of the author(s).

OECD Working Papers describe preliminary results or research in progress by the author(s) and are published to stimulate discussion on a broad range of issues on which the OECD works.

This series is designed to make available to a wider readership selected studies on environmental issues prepared for use within the OECD. Authorship is usually collective, but principal author(s) are named.

The papers are generally available only in their original language -English or Frenchwith a summary in the other language.

Comments on OECD Working Papers are welcomed, and may be sent to:

OECD Environment Directorate, 2, rue André Pascal, 75775 PARIS CEDEX 16, France or by e-mail to env.contact@oecd.org”

OECD Environment Working Papers are published on www.oecd.org/env/workingpapers.htm

This document and any map included herein are without prejudice to the status of or sovereignty over any territory, to the delimitation of international frontiers and boundaries and to the name of any territory, city or area.

The statistical data for Israel are supplied by and under the responsibility of the relevant Israeli authorities. The use of such data by the OECD is without prejudice to the status of the Golan Heights, East Jerusalem and Israeli settlements in the West Bank under the terms of international law.

\section{(C) OECD (2014)}

You can copy, download or print OECD content for your own use, and you can include excerpts from OECD publications, databases and multimedia products in your own documents, presentations, blogs, websites and teaching materials, provided that suitable acknowledgment of OECD as source and copyright owner is given.

All requests for commercial use and translation rights should be submitted to rights@oecd.org 


\begin{abstract}
This report focuses on households' behaviour in relation to water use. It presents the results of followup analysis of the 2011 OECD Survey on Environmental Policy and Individual Behaviour Change (EPIC) where econometric techniques are applied. This report complements the overview of the survey data provided in the publication OECD (2014). The analysis shows that households whose bill depends on actual water use are unambiguously more likely to exhibit pro-environmental behaviours in terms of water use, including undertaking water-saving behaviours, purchasing water-efficient devices, and taking water efficiency into account when purchasing such equipment. The results also confirm that the effect of social norms, attitudes, and opinions about the environment in general do matter in explaining households' behaviour and investment decisions. The main policy recommendations that can be derived from this study are: to charge households for water based on their actual water use and to pursue individuals' sensitisation to environmental issues by promoting water-conservation behaviours through campaigns and advertising, primarily targeting male and young adults.
\end{abstract}

JEL Classification: C51, D11, D12, Q25, Q58.

Keywords: Environmental attitudes, labelling, tap water, water-saving behaviour, investment in water-efficient devices, water quality, household survey.

\title{
RÉSUMÉ
}

Ce rapport est consacré au comportement des ménages en matière de consommation d'eau. Il présente les résultats de travaux d'analyse qui s'inscrivent dans le prolongement de l'enquête sur la politique de l'environnement et le comportement individuel (EPIC) réalisée par l'OCDE en 2011, et qui ont donné lieu à l'application de techniques économétriques. Ce rapport complète la synthèse des données de l'enquête présentée dans l'ouvrage OCDE (2014). L'analyse des résultats de l'enquête montre que les ménages dont les factures dépendent de leur consommation réelle ont nettement plus de chances de faire preuve d'un comportement soucieux de l'environnement, en décidant de faire des économies, en investissant dans des appareils à faible consommation d'eau et en prenant en compte la consommation d'eau lors de l'achat d'appareils. Les résultats confirment également que les normes sociales, les attitudes et les opinions relatives à l'environnement en général ont leur importance dans l'explication du comportement des ménages et de leurs décisions d'investissement. Les principales recommandations d'action que l'on peut tirer de l'étude sont les suivantes : faire payer aux ménages leur consommation réelle et continuer de sensibiliser les individus aux questions d'environnement en encourageant les comportements économes en eau par des campagnes publicitaires et autres, ciblant surtout les hommes et les jeunes adultes.

Classification JEL : C51, D11, D12, Q25, Q58.

Mots-clés: attitudes envers l'environnement, étiquetage, eau du robinet, comportement d'économie d'eau, investissement dans des dispositifs économes en eau, qualité de l'eau, enquête ménages. 
TABLE OF CONTENTS

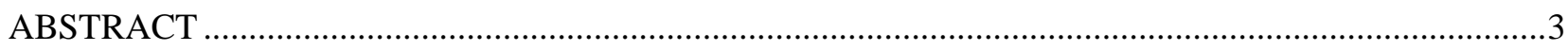

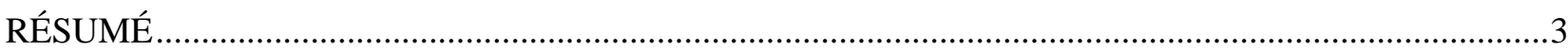

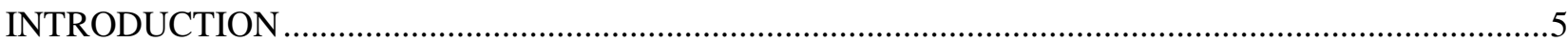

BRIEF SUMMARY OF THE ECONOMETRIC APPROACHES AND METHODOLOGICAL ASPECTS7

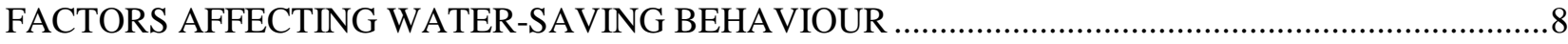

FACTORS AFFECTING THE ADOPTION OF WATER-EFFICIENT DEVICES .................................12

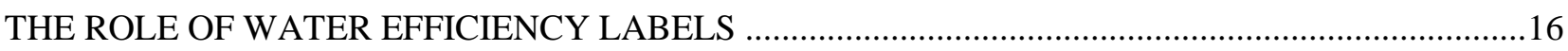

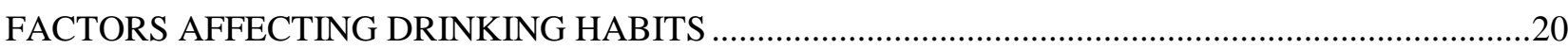

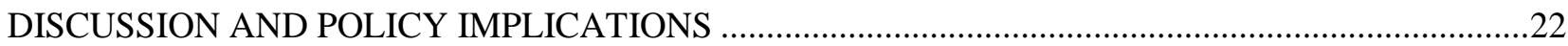

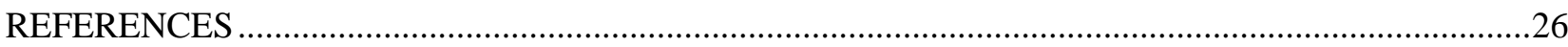

ANNEX 1: FACTORS INFLUENCING WATER-SAVING BEHAVIOUR: MAIN RESULTS FROM

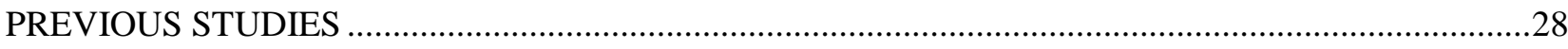

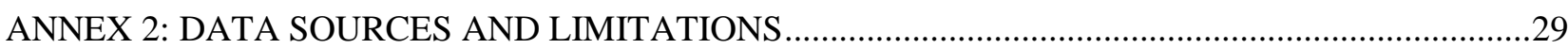

APPENDIX A: PROBIT MODEL WITH SAMPLE SELECTION ……...................................................

APPENDIX B: LIST AND DEFINITION OF THE VARIABLES USED IN THE REPORT .....................31

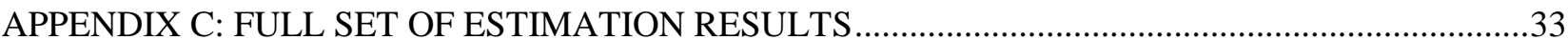

\section{Tables}

Table 1. Reported individual water metering and water-saving behaviours (country mean) .....................8

Table 2. Factors affecting the likelihood to always undertake water-saving behaviours .........................10

Table 3. Reported individual metering and purchase of water-efficient devices (country mean) ..............12

Table 4. Factors affecting the likelihood to invest in water-efficient devices ..........................................14

Table 5. Factors affecting the likelihood of taking water efficiency into account .....................................17

Table 6. Factors affecting the likelihood of using water-efficiency labels ............................................18

Table 7. Influence of labelling schemes on purchase decisions............................................................19

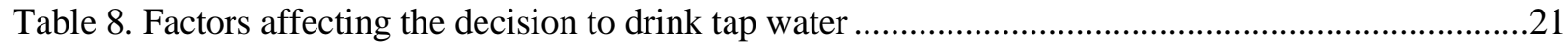

Table C1. Likelihood to always undertake water-saving behaviours ......................................................33

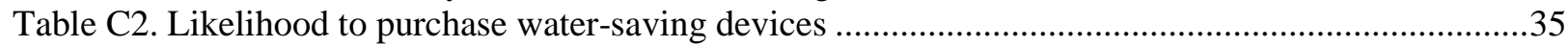

Table C3.1. Likelihood of taking water-efficiency into account ............................................................37

Table C3.2. Likelihood of using water efficiency labels (Australia, Israel, and the Netherlands) .............38

Table C3.3. The role of water efficiency labels in driving adoption of water-efficient devices.................39

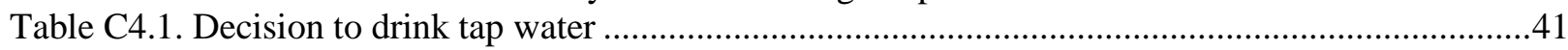

\section{Figures}

Figure 1. Share of households reporting 'always' undertaking water-saving behaviours, by type of water

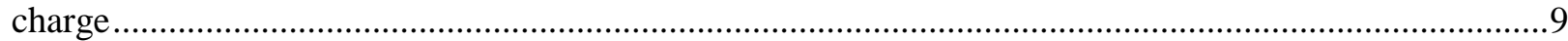

Figure 2. Share of households owning water-efficient equipment, by type of water fee.........................13 


\section{INTRODUCTION}

Increasing scarcity of natural resources and environmental degradation in general has induced a number of governments to launch policies that provide incentives to households to reduce their impact on the environment. Economic incentives, often provided through prices, subsidies, and tax incentives, are sometimes combined with initiatives that aim at raising households' awareness such as eco-labelling or sensitisation campaigns.

The impact these policies have on households' decisions and behaviour is difficult to assess for a number of reasons. First, policies rarely come in isolation (for example, an increase in the price of water will often be accompanied by a campaign on water savings) which makes it difficult to identify the impact of each policy separately. Second, households have heterogeneous characteristics and preferences, and may have heterogeneous reactions to each of these policies. Third, households may be willing to undertake actions to protect the environment for other reasons than simple economic motives so households' awareness and opinion about the state of the environment in general have to be taken into account.

This type of analysis thus requires a comprehensive household-level dataset with significant variation in policies and a large set of household and respondent characteristics. The OECD Survey on Environmental Policy and Individual Behaviour Change (EPIC) provides a unique opportunity to improve our understanding of households' decision making in terms of environmental behaviour in general, and of the role of public policies in particular. The 2011 EPIC survey is the second and latest round of the OECD household survey on environmental behaviour. ${ }^{1}$ It was implemented in early 2011 and covered more than 12000 households in 11 countries: Australia, Canada, Chile, France, Israel ${ }^{2}$, Japan, Korea, the Netherlands, Spain, Sweden and Switzerland. The two rounds of the EPIC Survey were implemented using the Internet and responses to the questionnaire were collected by means of online household panels in different countries. For representativity, the sample was stratified in each country according to different parameters: age, gender, region and socio-economic groups. ${ }^{3}$ This follow-up analysis complements the overview of the survey data provided in the publication OECD (2014).

The purpose of this study is to identify causal relationships between policies and behaviours in the water sector. Identification can only come from the cross-sectional variation in the data since households in our sample have been observed only once. We do not follow households over time but instead we take a snapshot of a population at one specific point in time. So we are not observing how each household responds to a change in policy. On the contrary we are looking across all households and identification relies on households in different countries facing different policies. However one cannot simply compare behaviour of households in different countries to assess the causal impact of policies on behaviour. In order to isolate the effect of policies, we need to take into account all the other factors that could possibly influence behaviour.

\footnotetext{
${ }^{1}$ The first EPIC survey was conducted in 2008 in 10 countries.

${ }^{2}$ The statistical data for Israel are supplied by and under the responsibility of the relevant Israeli authorities. The use of such data by the OECD is without prejudice to the status of the Golan Heights, East Jerusalem and Israeli settlements in the West Bank under the terms of international law.

${ }^{3}$ More details on the survey implementation are provided in (OECD, 2014). See Annex B.
} 
The academic literature in general and the analysis of the 2008 OECD EPIC survey in particular, have already identified important factors influencing water-saving behaviour that we will further examine. ${ }^{4}$ These include environmental attitudes and norms. Households' level of concern over environmental issues has for instance proven important as far as water use is concerned. Economic and demographic characteristics also play a role. A number of decisions have direct economic consequences: for example, the decision to purchase a water-efficient washing machine will likely depend on the expected savings (in terms of water use and water bill) as well as on the cost of the equipment. So variables such as household size, age of the household members, and income should be added as controls. Ownership status is also an important control variable, in particular when focusing on water-saving equipment. Renters usually do not have the possibility to choose the type of appliances they want to put in their rented apartment or house.

In what follows we present and discuss econometric models that focus on three aspects of households' behaviour in relation to water use: first, households' water-saving habits ${ }^{5}$, second, the adoption of waterefficient devices (i.e. low volume or dual flush toilets; water flow restrictor taps/low flow shower heads; and water tanks to collect rainwater), and third, households' decision to drink water from the tap.

The study mainly focuses on two specific policies: individual metering and labelling of water-efficient appliances. We hypothesise that households being individually metered and charged based on the volume of water they use should have a higher propensity to undertake water-saving behaviour and to purchase water-efficient appliances. We expect individual metering to convey a signal on the price of water to the household and to provide incentives for water saving. Labelling provides information to the consumers. This report helps us better understand the factors driving households' knowledge of water-efficiency labels and the potential influence of this knowledge on purchasing decision.

The next section provides a summary of the major methodological issues to be dealt with in this study. Sections 3 to 6 present models and empirical results. Factors affecting water-saving behaviour and the adoption of water-efficient devices are examined as well as the role of water efficiency labels and the determinants of drinking habits. In Section 7, we summarise the main findings, and derive some policy implications. The results are also contrasted with previous findings based on the 2008 EPIC survey and findings from the literature.

\footnotetext{
${ }^{4}$ See Annex 1.

${ }^{5}$ Five water-saving habits are examined in the survey: turning off the water while brushing teeth; plugging the sink when washing dishes by hand; watering garden in the coolest part of the day; collecting rainwater or recycling wastewater and taking showers instead of baths.
} 
ENV/WKP(2014)11

\section{BRIEF SUMMARY OF THE ECONOMETRIC APPROACHES AND METHODOLOGICAL ASPECTS}

Running an econometric analysis first requires making decisions on model specification, which includes defining the dependent variable (i.e. the behaviour or decision to be explained) and choosing the set of (exogenous) explanatory factors. Second, one needs to identify the most appropriate econometric technique to estimate the unknown parameters of these models. The most appropriate econometric technique is the one that produces consistent and efficient estimates of the unknown coefficients. Consistency implies that the estimated parameters are unbiased and efficiency means that they have the highest precision (or lowest standard errors).

A number of decisions analysed in this report are in the form of categorical variables (i.e. they can take on one of a limited, and usually fixed, number of possible values), which call for the use of econometric models describing the likelihood of specific values being chosen (i.e. probit/logit type of models). Some of these decisions may not be relevant for some households who, consequently, could not answer the corresponding question. For example, the question about 'garden watering' cannot be answered by households who do not have any garden. Similarly, questions about investment in water-efficient devices may not be relevant for renters if the owners are in charge of purchasing this type of goods. These respondents are thus excluded from the sample used to estimate the decision models. If the reason why they could not answer the question is, in some sense, related to the water-saving behaviour under consideration, then simply overlooking these households will create a bias at the estimation stage (commonly known as 'sample selection bias').

In econometric terms, selection bias would occur if some unobserved characteristics influence both the reason why the respondent cannot answer to the question and his/her water-saving behaviour. The common approach to test and control for selection bias is to estimate a selection equation simultaneously with the model of interest. A non-zero correlation between the error terms of the two equations would indicate presence of selection bias. The difficulty is to find appropriate instruments for the selection equation: for example, a good instrument is a variable that influences households' decision to live in a place without garden, but not their practices of garden watering (for greater details on Probit models with sample selection, see Appendix A).

We will control for possible sample selection bias when modelling the following decisions:

- Watering one's garden in the coolest part of the day (3,925 households, i.e. $32 \%$ of the sample, did not respond to this question);

- Collecting rainwater or recycling wastewater (3,189 households, $26 \%$ of the sample);

- Purchasing water-saving appliances (low volume or dual flush toilets, water flow restrictor taps/low flow shower heads, and water tanks).

The use and effectiveness of water-efficient labels is another issue to be addressed in this study. More precisely, we test if households who use water-efficiency labels are more likely to purchase water-efficient equipment. One difficulty here is that awareness and use of labels cannot be considered exogenous in the models describing purchase decisions. One can easily imagine that households who are willing to purchase a water-efficient device will (simultaneously) gather information about water-efficiency labels. One way of addressing this issue is to estimate the purchase decision in two stages, with the first-stage describing the probability of using water-efficiency labels. This procedure requires the use of instruments in the first stage, i.e. variables that would influence the use of water labels but not the purchasing decision.

The following sections describe the main variables of interest and summarise the key findings. The list of variables used in this report and their definition is available in Appendix B. Detailed estimation results are gathered in Appendix C. 


\section{FACTORS AFFECTING WATER-SAVING BEHAVIOUR}

\section{Description of the variables of interest}

Each respondent had to state how often he/she was undertaking each of the following five watersaving behaviours: turning off the water while brushing teeth; plugging the sink when washing dishes by hand; watering the garden in the coolest part of the day; collecting rainwater or recycling wastewater; taking showers instead of baths. Possible answers were 'never', 'occasionally', 'often', 'always', and 'not applicable'. This type of answer would call for the building of a categorical variable that would take four values such as 1 if 'never', 2 if 'occasionally', 3 if 'often', and 4 if 'always'. This approach however suffers from two drawbacks: first, it implies that we consider the distance between 'never' and 'occasionally' and the distance between 'occasionally' and 'often' as exactly equivalent. Second, interpretation of 'occasionally' versus 'often' may differ across respondents, whereas 'never' and 'always' are less ambiguous. In what follows, we propose to build a dummy variable that takes the value 1 if the respondent 'always' performs the behaviour and 0 otherwise. ${ }^{6}$ Based on this definition, the respondents who answered 'not applicable' are dropped from the analysis.

We present some basic descriptive statistics on the main variables of interest in Table 1. On a countryby-country basis this table shows the proportion of households individually metered and the proportion of households always undertaking each of the five behaviours.

Table 1. Reported individual water metering and water-saving behaviours (country mean)

\begin{tabular}{lcccccc}
\hline & $\begin{array}{c}\text { Individual } \\
\text { Water } \\
\text { metering }\end{array}$ & $\begin{array}{c}\text { Always } \\
\text { (Turning off } \\
\text { water) }\end{array}$ & $\begin{array}{c}\text { Always } \\
\text { (Plugging the } \\
\text { sink) }\end{array}$ & $\begin{array}{c}\text { Always } \\
\text { (Watering the } \\
\text { garden) }\end{array}$ & $\begin{array}{c}\text { Always } \\
\text { (Collecting or } \\
\text { recycling } \\
\text { water) }\end{array}$ & $\begin{array}{c}\text { Always } \\
\text { (Taking } \\
\text { showers) }\end{array}$ \\
\hline Australia & $75 \%$ & $69 \%$ & $70 \%$ & $70 \%$ & $44 \%$ & $86 \%$ \\
Canada & $36 \%$ & $53 \%$ & $59 \%$ & $53 \%$ & $19 \%$ & $70 \%$ \\
Chile & $91 \%$ & $54 \%$ & $22 \%$ & $70 \%$ & $7 \%$ & $76 \%$ \\
France & $81 \%$ & $70 \%$ & $48 \%$ & $65 \%$ & $43 \%$ & $79 \%$ \\
Israel & $84 \%$ & $69 \%$ & $11 \%$ & $58 \%$ & $11 \%$ & $81 \%$ \\
Japan & $92 \%$ & $69 \%$ & $15 \%$ & $16 \%$ & $12 \%$ & $14 \%$ \\
Korea & $82 \%$ & $61 \%$ & $13 \%$ & $9 \%$ & $7 \%$ & $65 \%$ \\
Netherlands & $87 \%$ & $53 \%$ & $63 \%$ & $52 \%$ & $25 \%$ & $71 \%$ \\
Spain & $82 \%$ & $74 \%$ & $33 \%$ & $59 \%$ & $14 \%$ & $87 \%$ \\
Sweden & $33 \%$ & $46 \%$ & $41 \%$ & $36 \%$ & $20 \%$ & $70 \%$ \\
Switzerland & $51 \%$ & $60 \%$ & $33 \%$ & $45 \%$ & $25 \%$ & $63 \%$ \\
\hline
\end{tabular}

Note: (1) Turn off the water while brushing teeth; (2) Plug the sink when washing dishes by hand; (3) Water the garden in the coolest part of the day; (4) Collect rainwater or recycle wastewater; (5) Take showers instead of baths.

\footnotetext{
${ }^{6}$ The estimation results remain qualitatively equivalent when we group together the respondents who are often adopting pro-environmental behaviours with those who are always adopting pro-environmental behaviours.
} 
Individual metering varies from about one-third in water-abundant countries (Sweden, Canada) to $92 \%$ in Japan. We also observe significant differences across countries as far as water-saving behaviours are concerned. For example, less than $20 \%$ of the respondents from Japan and Korea declared always watering garden in the coolest part of the day, while this proportion is higher than $65 \%$ in France, Chile, and Australia. The proportions of households always undertaking water-saving behaviours in Australia and France are often among the highest of all countries, which may be a consequence of active water-saving campaigns in Australia and a relatively high price of water in France (see OECD, 2011 and Grafton et al., 2011).

Figure 1. Share of households reporting 'always' undertaking water-saving behaviours, by type of water charge

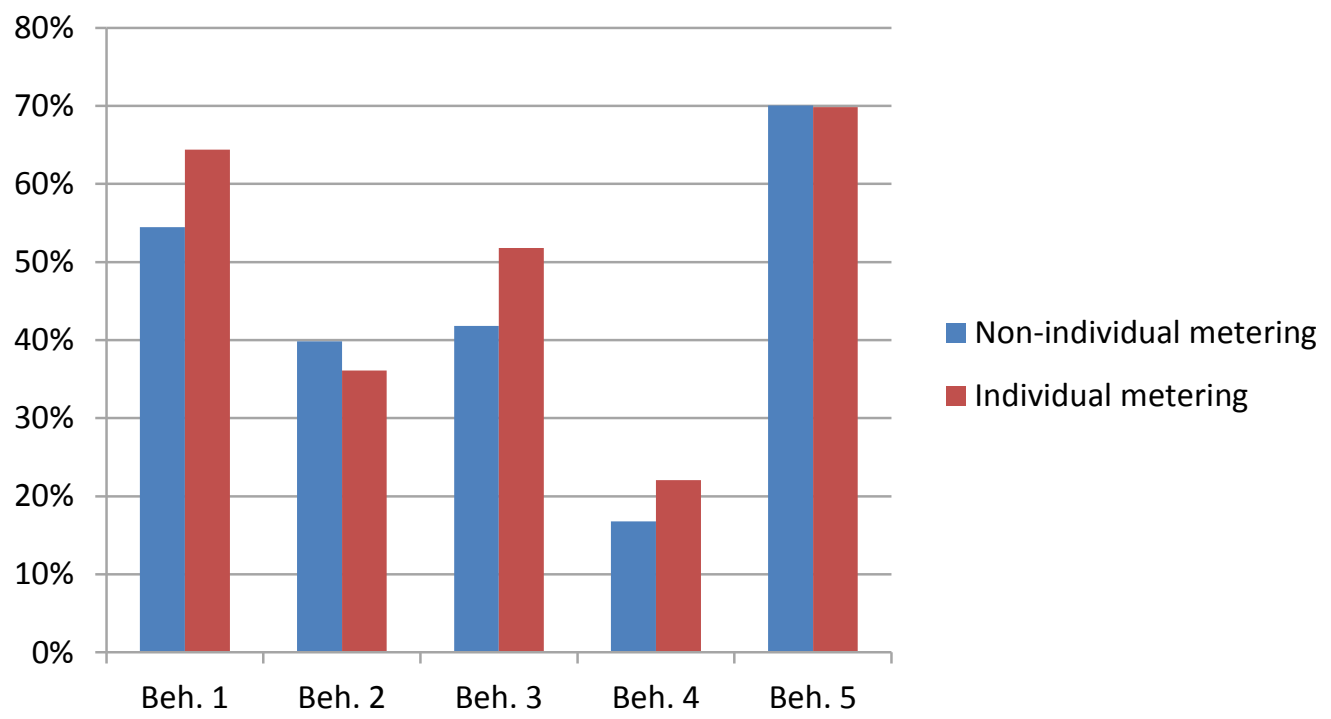

Behaviour 1: Always turning off the water while brushing teeth; Behaviour 2: Always plugging the sink when washing dishes by hand; Behaviour 3: Always watering garden in the coolest part of the day; Behaviour 4: Always collecting rainwater or recycling wastewater; Behaviour 5: Always taking showers instead of baths.

On the pooled sample, we find that the share of households always turning off the water while brushing teeth, always watering garden in the coolest part of the day and always collecting rainwater or recycling wastewater is slightly higher among households who are individually metered (Figure 1). We find the opposite effect for the second behaviour (always plugging the sink when washing dishes by hand) and no effect for the fifth (always taking showers instead of baths). Tests of means equality indicate that the proportions of households adopting the first four water-saving behaviours are statistically different between the two groups of households (those with individual metering and those without).

\section{Methodological issues and approach}

We estimate a selection equation along with the main model of interest (Probit model with sample selection $)^{7}$ for the following two behaviours: watering garden in the coolest part of the day and collecting rainwater or recycling wastewater. If the correlation coefficient between the error terms of the two equations is not statistically different from zero, estimates from the simple Probit model are more efficient and will thus be reported. For the other three behaviours (plugging the sink when washing dishes by hand, turning off the water while brushing teeth, and taking showers instead of baths), we estimate a single

\footnotetext{
${ }^{7}$ Estimated using the heckprob procedure in Stata.
} 
Probit. In each of these models, country-specific effects are included, sampling weights are taken into account, and standard errors that are robust to heteroskedasticity are calculated.

\section{Main findings}

The full set of estimation results identifying factors driving the five water-saving behaviours (along with goodness-of-fit measures) are shown in Table $\mathrm{C} 1$ in the Appendix. A summary of the main findings is provided in Table 2. We report estimated marginal effects and statistical significance for the five Probit models describing the likelihood that respondents always undertake each of the five behaviours (country dummies not shown here).

Table 2. Factors affecting the likelihood to always undertake water-saving behaviours

(Probit model estimated marginal effects and statistical significance)

\begin{tabular}{|c|c|c|c|c|c|}
\hline & $\begin{array}{l}\text { Turning } \\
\text { off water }^{1}\end{array}$ & $\begin{array}{l}\text { Plugging } \\
\text { the sink }\end{array}$ & $\begin{array}{l}\text { Watering } \\
\text { the garden }\end{array}$ & $\begin{array}{l}\text { Collecting/ } \\
\text { recycling } \\
\text { water }^{4}\end{array}$ & $\begin{array}{l}\text { Taking } \\
\text { showers }\end{array}$ \\
\hline Unit water charge & $0.046 * *$ & $0.048 * * *$ & $0.086 * * *$ & $0.048 * *$ & 0.014 \\
\hline Unit water charge (do not know) & $-0.091 * *$ & -0.016 & -0.027 & 0.013 & -0.042 \\
\hline Gender $($ male $=1)$ & $-0.056 * * *$ & 0.007 & $-0.069 * * *$ & $-0.040 * *$ & 0.011 \\
\hline Age of respondents & $-0.001 * *$ & $0.002 * * *$ & $0.003 * * *$ & $0.002 * * *$ & 0.000 \\
\hline $\begin{array}{l}\text { Education } \\
\text { (respondent completed at least one year of } \\
\text { education after high school }=1 \text { ) }\end{array}$ & -0.024 & -0.015 & 0.035 & -0.025 & 0.014 \\
\hline $\log \mathrm{INC}^{8}$ & $-0.026^{*}$ & -0.010 & -0.011 & $-0.039 * *$ & $-0.048 * * *$ \\
\hline $\begin{array}{l}\text { Ownership status } \\
(\text { ownership of the residence }=1)\end{array}$ & $0.032 *$ & 0.018 & $-0.050 *$ & -0.038 & $-0.060 * * *$ \\
\hline Score on "environmental concern" index ${ }^{9}$ & $0.030 * * *$ & $0.016 * * *$ & $0.051 * * *$ & $0.033 * * *$ & $0.017 * *$ \\
\hline Supporting environmental organisation & $0.081 * * *$ & $0.062 * * *$ & $0.063 * *$ & $0.056^{*}$ & -0.013 \\
\hline $\begin{array}{l}\text { Voting } \\
\text { (voted in local or national } \\
\text { elections in the past six years }=1 \text { ) }\end{array}$ & $0.045 * *$ & $0.053 * * *$ & 0.019 & $0.043^{*}$ & $-0.067 * *$ \\
\hline $\begin{array}{l}\text { Disagreement with the statement } \\
\text { "environmental impacts are frequently } \\
\text { overstated" }\end{array}$ & $-0.013 *$ & 0.009 & 0.005 & $0.012 *$ & 0.006 \\
\hline $\begin{array}{l}\text { Disagreement with the statement } \\
\text { "environmental issues will be resolved in any } \\
\text { case through technological progress" }\end{array}$ & $0.012 *$ & -0.006 & 0.001 & 0.000 & -0.003 \\
\hline
\end{tabular}

Note: (1) Turn off the water while brushing teeth; (2) Plug the sink when washing dishes by hand; (3) Water the garden in the coolest part of the day; (4) Collect rainwater or recycle wastewater; (5) Take showers instead of baths.

*** $p<0.01,{ }^{* *} p<0.05,{ }^{*} p<0.1$

Male respondents are less likely to always undertake three types of water-saving behaviours: turning off the water while brushing teeth, watering garden in the coolest part of the day, and collecting rainwater

\footnotetext{
${ }^{8}$ The variable that is used is the logarithm of imputed income (respondents only stated the interval of their household's income).

${ }^{9}$ This index reflects concern about environmental issues in general. A higher value means more concern about the environment. Results from question 23 are used to calculate it.
} 
or recycling wastewater. Older respondents are more likely to always plug the sink when washing dishes by hand, water garden in the coolest part of the day, and collect rainwater or recycle wastewater; but less likely to always turn off the water while brushing teeth. ${ }^{10}$ Education (more precisely having a post high school education) is not found significant in any of the models while income is found to decrease the likelihood of undertaking water-saving behaviours in general (significant for all five behaviours except for plugging the sink when washing dishes by hand and watering garden in the coolest part of the day). Owners are found to be less likely to always water garden in the coolest part of the day and to always take showers instead of baths. However the ownership status increases the propensity to always turn off the water while brushing teeth and to always collect rainwater or recycle wastewater.

Respondents who express higher concerns about the environment in general ("environmental concern index") are more likely to always undertake the five water-saving behaviours. Being a member or supporting an environmental group/association also increases the probability of undertaking water-saving behaviours. ${ }^{11}$ Respondents who have voted in local or national elections in the past six years are also, in general, more likely to undertake water-saving behaviours except that they have a lower likelihood of always taking showers instead of baths. Finally, respondents who are in disagreement with the statement that 'environmental impacts are frequently overstated' are more likely to always collect rainwater or recycle wastewater but less likely to always turn off the water while brushing teeth. Those who were in disagreement with the idea that 'environmental issues will be resolved in any case through technological progress' were more likely to always turn off the water while brushing teeth.

Respondents for whom water use is individually metered are more likely to undertake all five watersaving behaviours (significant in all cases except for the last one: always taking showers instead of baths). Those respondents who did not know whether they were individually metered are also less likely to always turn off water while brushing teeth.

The marginal effects of the variables that are found to influence water-saving behaviours are all in the range of 0.04-0.08 (i.e. they increase the probability of adopting the corresponding water-saving behaviour by $4 \%$ to $8 \%)$.

Results from the selection equations (in model (3) explaining the decision to always water the garden in the coolest part of the day and (4) to always collect rainwater or recycling wastewater) show that being an owner and living outside a major town/city and outside a suburban area are important factors driving selection into the samples (Table $\mathrm{C} 1$ ).

We also tested whether the impact of individual metering was different across the eleven countries. We interacted the dummy variable indicating whether the household is charged based on its water use with country dummies in the five models. Individual metering is found to have a significant impact on the likelihood to adopt water-saving behaviours in Canada (significant in three models out of five), Chile (significant but negative in one model out of five), France (four models out of five), Israel (one model out of five), the Netherlands (two models out of five), Spain (one model out of five), Sweden (two models out of five), and Switzerland (three models out of five). It is not found significant in any of the five models in Australia, Japan, and Korea. ${ }^{12}$ The non-significance of the variable describing the type of water fee in Japan might be explained by the high proportion of households being individually metered in this country $(92 \%)$.

\footnotetext{
${ }^{10}$ We tested non-linear effects of age by including the square of the age variable in the five models. This variable was not found significant at usual levels of significance, in general.

${ }^{11}$ Significant in all cases except for taking showers instead of baths, maybe for the reason that the habit of taking baths is an habit that respondents find more difficult to change than the other four.

${ }^{12}$ Estimation results are not shown here but are available upon request.
} 


\section{FACTORS AFFECTING THE ADOPTION OF WATER-EFFICIENT DEVICES}

\section{Description of the variables of interest}

The survey examines the adoption of the following three devices: low volume or dual flush toilets, water flow restrictor taps/low flow shower heads, and water tanks to collect rainwater. Each respondent had to answer by 'yes', 'no', 'already equipped' or 'not possible' to the following question: 'has your household invested in the following appliances/devices in the past ten years in your current primary residence?' In what follows the main variable of interest, for each type of device, will take the value 1 if the respondent invested in such a device in the past ten years, and 0 otherwise.

Table 3 presents the proportion of households who reported that they are being individually metered and the proportion of households who reported that they purchased water-saving equipment on a countryby-country basis.

Table 3. Reported individual metering and purchase of water-efficient devices (country mean)

\begin{tabular}{cccc}
\hline $\begin{array}{c}\text { Individual } \\
\text { metering }\end{array}$ & $\begin{array}{c}\text { Water flow } \\
\text { restrictor taps/low } \\
\text { flow shower heads }\end{array}$ & $\begin{array}{c}\text { Low-volume or } \\
\text { dual flush toilets }\end{array}$ & Water tanks \\
\hline
\end{tabular}

\begin{tabular}{lcccc} 
Australia & $75 \%$ & $70 \%$ & $73 \%$ & $38 \%$ \\
Canada & $36 \%$ & $55 \%$ & $42 \%$ & $18 \%$ \\
Chile & $91 \%$ & $48 \%$ & $31 \%$ & $5 \%$ \\
France & $81 \%$ & $49 \%$ & $66 \%$ & $42 \%$ \\
Israel & $84 \%$ & $67 \%$ & $74 \%$ & $9 \%$ \\
Japan & $92 \%$ & $23 \%$ & $21 \%$ & $4 \%$ \\
Korea & $82 \%$ & $37 \%$ & $17 \%$ & $5 \%$ \\
Netherlands & $87 \%$ & $69 \%$ & $63 \%$ & $20 \%$ \\
Spain & $82 \%$ & $56 \%$ & $53 \%$ & $8 \%$ \\
Sweden & $33 \%$ & $46 \%$ & $48 \%$ & $15 \%$ \\
Switzerland & $51 \%$ & $55 \%$ & $42 \%$ & $19 \%$ \\
\hline
\end{tabular}

Reported adoption rates for the three types of devices vary by country. Water tanks for example have been adopted by about $5 \%$ of the surveyed households in Japan and Korea while adoption rate is close to 40\% in Australia and France.

On the pooled sample, the share of households who purchased the three water-efficient devices is slightly higher among households who are individually metered (Figure 2). Tests of mean equality confirm that the average proportions are statistically different between the two groups of households (with and without individual metering) for all three types of devices. 
Figure 2. Share of households owning water-efficient equipment, by type of water fee

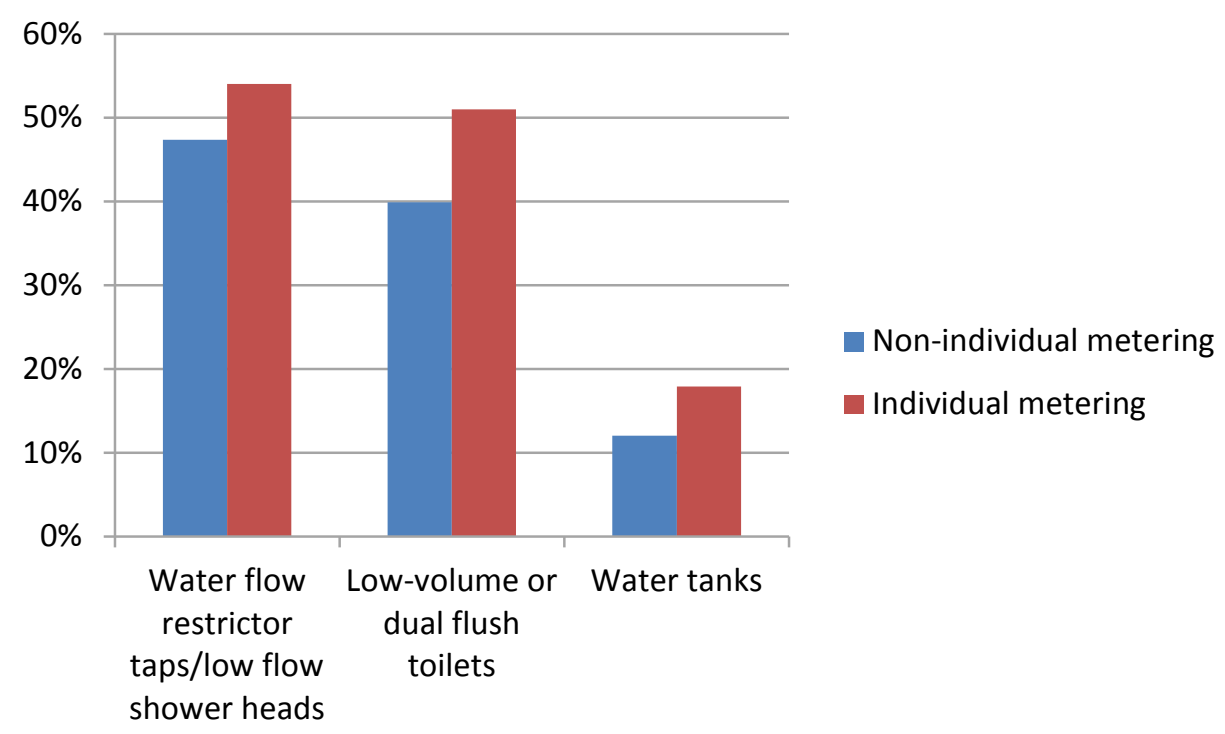

\section{Methodological issues and approach}

We estimate a selection equation along with the main model of interest (Probit model with sample selection $)^{13}$ to describe adoption of the three devices. If the correlation coefficient between the error terms of the two equations is not statistically different from zero, estimates from the simple Probit model is reported. In each of these models country-specific effects are included, sampling weights are taken into account, and standard errors that are robust to heteroskedasticity are calculated.

\section{Main findings}

The full set of estimation results (along with goodness-of-fit measures) is shown in Appendix C (Table C2). A summary of the main findings is provided in Table 4. We report estimated marginal effects and statistical significance for the three Probit models describing the likelihood that respondents have invested in each of the three devices in the past ten years (country dummies not shown here).

\footnotetext{
${ }^{13}$ Estimated using the heckprob procedure in Stata.
} 
Table 4. Factors affecting the likelihood to invest in water-efficient devices

(Probit model estimated marginal effects and statistical significance)

\begin{tabular}{|c|c|c|c|}
\hline & $\begin{array}{l}\text { Water flow restrictor } \\
\text { taps/low flow shower } \\
\text { heads }\end{array}$ & $\begin{array}{l}\text { Low-volume or } \\
\text { dual flush toilets }\end{array}$ & Water tanks \\
\hline Unit water charge & $0.053 * *$ & $0.055^{* *}$ & $0.048 * * *$ \\
\hline Unit water charge (do not know) & -0.071 & 0.012 & 0.023 \\
\hline Gender $($ male $=1)$ & 0.017 & 0.027 & -0.001 \\
\hline Age of respondents & $0.003 * * *$ & $0.003 * * *$ & 0.001 \\
\hline Household size & $0.021 * * *$ & $0.023 * * *$ & $0.009 *$ \\
\hline $\log \mathrm{INC}$ & 0.014 & 0.012 & $-0.033 * *$ \\
\hline Score on "environmental concern" index & $0.025 * * *$ & 0.007 & $0.013 * * *$ \\
\hline Supporting environmental organisation & $0.103 * * *$ & $0.146^{* * *}$ & $0.096 * * *$ \\
\hline $\begin{array}{l}\text { Voting } \\
\text { (voted in local or national } \\
\text { elections in the past six years }=1 \text { ) }\end{array}$ & $0.091 * * *$ & $0.059 * *$ & $0.060 * * *$ \\
\hline $\begin{array}{l}\text { Disagreement with the statement } \\
\text { "environmental impacts are frequently } \\
\text { overstated" }\end{array}$ & $-0.013 *$ & -0.011 & 0.005 \\
\hline $\begin{array}{l}\text { Disagreement with the statement } \\
\text { "environmental issues will be resolved in any } \\
\text { case through technological progress" }\end{array}$ & 0.003 & -0.007 & -0.003 \\
\hline
\end{tabular}

Note: ${ }^{* * *} p<0.01,{ }^{* *} p<0.05,{ }^{*} p<0.1$

The likelihood of investing in water-efficient devices is higher for older respondents (significant for both low-volume or dual flush toilets and water flow restrictor taps/low flow shower heads). ${ }^{14}$ Larger households have a higher probability to invest in the three types of water-saving equipment. Wealthier households are found to be less likely to invest in water tanks (we find an opposite, but non-significant, effect for the other two types of devices). We find selection to be important when estimating adoption of low-volume/dual flush toilets and water tanks (see estimates of the selection equation in Table C2, Appendix C). In particular, households owning their property and households with a higher income are found to self-select into the samples of households who answered the question about the purchase of such equipment. This implies that households found in the sub-samples used to estimate the models describing investment in these two types of equipment are wealthier and more likely to own their property than households in the overall sample.

Respondents who express a higher environmental concern, those who are members of or support an environmental group/association, and those who voted in local or national elections in the past six years are more likely to invest in water-efficient devices. Our results finally show that respondents who disagreed with the statement 'environmental impacts are frequently overstated' have a lower probability of investing in water flow restrictor taps/low flow shower heads. The estimated marginal effect of being a member of or supporting an environmental group/association varies between $10 \%$ and $15 \%$ and is the strongest of all marginal effects.

\footnotetext{
${ }^{14}$ We tested for non-linear effects of age by including the square of the age variable in the three models. This variable was not found significant at usual levels of significance.
} 
Being charged individually for water use significantly increases the likelihood of purchasing waterefficient devices. The corresponding marginal effect is estimated at 5\%. A country-by-country analysis produces fewer significant coefficients than the analysis made on the pooled sample in general but it is interesting to check whether our result that being charged individually for water use significantly increases the likelihood of purchasing water-efficient devices holds in a number of countries. We find that this result holds in Australia (for one out of three devices), Canada (two out of three), France (two out of three), Israel (one out of three), the Netherlands (one out of three), Spain (one out of three), Sweden (two out of three), and Switzerland (two out of three). Individual metering was not found significant in Chile, Japan, and Korea.

\section{The role of subsidy programs}

Respondents who invested in one of the three appliances in the past ten years were also asked if they had benefited from government (or utility company) financial support to make this investment. Because this question had to be answered only by those respondents who had purchased a water-efficient device, we cannot identify (using an econometric model) the impact of the subsidy on the likelihood of purchasing the equipment. A simple statistical analysis of the corresponding answers shows that 1,032 respondents benefited from financial support for purchasing water flow restrictor taps/low flow shower heads, 541 for low volume or dual flush toilets, and 245 for rainwater tanks. Countries in which such subsidies seemed to be the most frequent are Australia, Canada, Israel, and France. There is no significant difference in terms of household income between those who benefited from a subsidy and those who did not. 


\section{THE ROLE OF WATER EFFICIENCY LABELS}

\section{Description of the variables of interest}

In this section, we focus on water efficiency labels, in particular we analyse the answer to the following question: 'Did you take water efficiency into account when you last purchased either a washing machine or a dishwasher?' In addition, we study respondents' awareness and use of specific water efficiency labels in three countries: Australia, Israel, and the Netherlands. Finally, we test whether awareness of water efficiency labels may explain investment in two specific water-efficient devices: low volume or dual flush toilets and water flow restrictor taps/low flow shower heads.

\section{Methodological issues and approach}

The first question we analyse 'Did you take water efficiency into account when you last purchased either a washing machine or a dishwasher?' was answered only by respondents who recently purchased a washing machine or a dishwasher. We, again, have to control for possible selection bias.

Respondents from Australia, Israel, and the Netherlands were shown water efficiency labels in use in their countries and were asked, first, whether they understood the label; second, whether they trusted it; and, third, whether they used it. Overall, in the three countries, 94\% of the respondents declared understanding the label that was displayed, $87 \%$ declared that they trusted it, and $71 \%$ that they used it. In what follows we identify factors driving respondents' decision to use the water efficiency label in the three countries using a simple Probit model.

Finally, we test whether 'taking water efficiency into account' (either for the last purchase of a washing machine or a dishwasher, or through the use of water efficiency labels) increases the likelihood of respondents to invest in water-efficient devices. It is important to account for the fact that awareness and use of water efficiency labels may not be exogenous to the decision of purchasing water-efficient devices. We control for possible endogeneity of the variables measuring awareness/use of water efficiency labels by using predicted probabilities of awareness/use of water efficiency labels instead of respondents' answers. The predicted values are obtained from the Probit model with sample selection and simple Probit models described earlier.

\section{Main findings}

We first tried to identify factors driving respondents to 'take water efficiency into account when last purchasing either a washing machine or a dishwasher'. Estimated marginal effects are shown in Table 5 and full estimation results are shown in Table C3.1 in the Appendix.

We find that male respondents and respondents being members of smaller households were less likely to take water efficiency into account. Being a member or supporting an environmental organisation (largest marginal effect), expressing concern about the environment, and voting in elections are good predictors of the likelihood to take water efficiency into account when purchasing either a washing machine or a dishwasher. Finally, respondents for whom water use is individually metered are also more likely to take water efficiency into account while those who do not know how they are charged for water are less likely to take water efficiency into account. 
ENV/WKP(2014)11

Table 5. Factors affecting the likelihood of taking water efficiency into account

(Probit model estimated marginal effects and statistical significance)

\begin{tabular}{|c|c|c|c|}
\hline & $\begin{array}{c}\text { Marginal } \\
\text { effect }\end{array}$ & Std. Err. & $\mathrm{P}>\mathrm{z}$ \\
\hline Unit water charge & $0.044^{* *}$ & 0.020 & 0.025 \\
\hline Unit water charge (do not know) & $-0.112 * *$ & 0.045 & 0.012 \\
\hline Gender (male $=1$ ) & $-0.063 * * *$ & 0.015 & 0.000 \\
\hline Age of respondents & 0.001 & 0.001 & 0.131 \\
\hline Household size & $0.028 * * *$ & 0.006 & 0.000 \\
\hline $\log I N C$ & -0.013 & 0.018 & 0.481 \\
\hline Score on "environmental concern" index & $0.037 * * *$ & 0.006 & 0.000 \\
\hline Supporting environmental organisation & $0.129 * * *$ & 0.021 & 0.000 \\
\hline $\begin{array}{l}\text { Voting } \\
\text { (voted in local or national } \\
\text { elections in the past six years }=1 \text { ) }\end{array}$ & $0.102 * * *$ & 0.024 & 0.000 \\
\hline $\begin{array}{l}\text { Disagreement with the statement } \\
\text { "environmental impacts are frequently } \\
\text { overstated" }\end{array}$ & -0.005 & 0.006 & 0.430 \\
\hline $\begin{array}{l}\text { Disagreement with the statement } \\
\text { "environmental issues will be resolved in any } \\
\text { case through technological progress" }\end{array}$ & 0.005 & 0.006 & 0.423 \\
\hline
\end{tabular}

Note: ${ }^{* * *} p<0.01,{ }^{* *} p<0.05,{ }^{*} p<0.1$

We then turn our attention to the use of water efficiency labels in the three countries in which such labels were displayed: Australia, Israel, and the Netherlands. Estimated marginal effects are shown in Table 6 and full estimation results are shown in Table C3.2 in Appendix. Most of the findings are similar to the ones discussed above: male respondents are less likely to use a water efficiency label; those who express higher concern about the environment and support an environmental organisation are more likely to use water efficiency labels; and being charged for water through individual metering (marginal effect estimated at 11\%) increases the likelihood of using such labels. Our results finally show that respondents who disagreed with the statement that 'environmental impacts are frequently overstated' have a lower probability of using a water efficiency label. 
Table 6. Factors affecting the likelihood of using water-efficiency labels

(Probit model estimated marginal effects and statistical significance)

\begin{tabular}{|c|c|c|c|}
\hline & $\begin{array}{c}\text { Marginal } \\
\text { effect }\end{array}$ & Std. Err. & $\mathrm{P}>\mathrm{Z}$ \\
\hline Unit water charge & $0.107^{* *}$ & 0.042 & 0.012 \\
\hline Unit water charge (do not know) & -0.057 & 0.095 & 0.551 \\
\hline Gender $($ male $=1)$ & $-0.059 * *$ & 0.025 & 0.021 \\
\hline Age of respondents & 0.000 & 0.001 & 0.813 \\
\hline $\begin{array}{l}\text { Education } \\
\text { (respondent completed at least one year of } \\
\text { education after high school =1) }\end{array}$ & -0.036 & 0.028 & 0.203 \\
\hline $\log \mathrm{INC}$ & 0.034 & 0.024 & 0.155 \\
\hline Score on "environmental concern" index & $0.033 * * *$ & 0.009 & 0.000 \\
\hline Supporting environmental organisation & $0.066^{* *}$ & 0.030 & 0.030 \\
\hline $\begin{array}{l}\text { Voting } \\
\text { (voted in local or national } \\
\text { elections in the past six years }=1 \text { ) }\end{array}$ & 0.062 & 0.047 & 0.184 \\
\hline $\begin{array}{l}\text { Disagreement with the statement "environmental } \\
\text { impacts are frequently overstated" }\end{array}$ & $-0.020 *$ & 0.012 & 0.077 \\
\hline $\begin{array}{l}\text { Disagreement with the statement "environmental } \\
\text { issues will be resolved in any case through } \\
\text { technological progress" }\end{array}$ & 0.016 & 0.012 & 0.167 \\
\hline
\end{tabular}

We finally test if (1) having taken water efficiency labels into account when last purchasing a washing machine or a dishwasher and (2) using water labelling schemes (in Australia, Israel, and the Netherlands) influence the likelihood of investing in water-flow restrictor taps/low flow shower heads and low volume or dual flush toilet. Estimated marginal effects are shown in Table 7 and full estimation results are shown in Table C3.3 in Appendix C. We find a significant and positive effect of the probability of using a waterefficiency label when making purchase on the likelihood of buying a low volume or dual flush toilet (third model). In the first and third models, Australia is chosen as the reference for the country dummies. Almost all country-specific coefficients are negative and significant, indicating higher adoption rate of waterefficient devices in Australia compared to the other countries. 
Table 7. Influence of labelling schemes on purchase decisions

(Probit model estimated marginal effects and statistical significance)

\begin{tabular}{|c|c|c|c|c|}
\hline \multirow{2}{*}{$\begin{array}{l}\text { Dependent variable } \\
\text { Label variable }\end{array}$} & \multicolumn{2}{|c|}{$\begin{array}{l}\text { Adoption of water-flow } \\
\text { restrictor taps/low flow } \\
\text { shower heads }\end{array}$} & \multicolumn{2}{|c|}{$\begin{array}{c}\text { Adoption of low } \\
\text { volume or dual flush } \\
\text { toilet }\end{array}$} \\
\hline & $\begin{array}{l}\text { label } \\
\text { considered } \\
\text { at latest } \\
\text { purchase }\end{array}$ & $\begin{array}{l}\text { using } \\
\text { water } \\
\text { labelling } \\
\text { schemes }\end{array}$ & $\begin{array}{l}\text { label } \\
\text { considered } \\
\text { at latest } \\
\text { purchase }\end{array}$ & $\begin{array}{l}\text { using } \\
\text { water } \\
\text { labelling } \\
\text { schemes }\end{array}$ \\
\hline Unit water charge & $0.058 * *$ & 0.102 & 0.037 & 0.043 \\
\hline Unit water charge (do not know) & -0.077 & -0.027 & 0.061 & 0.034 \\
\hline Gender $($ male $=1)$ & 0.007 & -0.024 & $0.054 * *$ & 0.017 \\
\hline Age of respondents & $0.003 * * *$ & $0.004 * * *$ & $0.002 * * *$ & $0.002 *$ \\
\hline Household size & $0.025 * *$ & $0.030 * *$ & 0.010 & 0.006 \\
\hline $\begin{array}{l}\text { Education } \\
\text { (respondent completed at least one year of } \\
\text { education after high school }=1 \text { ) }\end{array}$ & -0.034 & 0.008 & - & - \\
\hline $\log \mathrm{INC}$ & - & - & 0.014 & -0.018 \\
\hline Score on "environmental concern" index & $0.026^{*}$ & $0.055 * * *$ & -0.010 & 0.008 \\
\hline Supporting environmental organisation & $0.103 * *$ & 0.082 & $0.096 * *$ & 0.013 \\
\hline $\begin{array}{l}\text { Voting } \\
\text { (voted in local or national } \\
\text { elections in the past six years }=1 \text { ) }\end{array}$ & $0.072 *$ & $0.141 * *$ & - & - \\
\hline $\begin{array}{l}\text { Disagreement with the statement } \\
\text { "environmental impacts are frequently } \\
\text { overstated" }\end{array}$ & -0.012 & -0.001 & -0.009 & 0.001 \\
\hline $\begin{array}{l}\text { Disagreement with the statement } \\
\text { "environmental issues will be resolved in any } \\
\text { case through technological progress" }\end{array}$ & 0.006 & $0.035^{*}$ & -0.009 & 0.001 \\
\hline $\begin{array}{l}\text { Predicted probability of considering water- } \\
\text { efficiency label when last purchasing a } \\
\text { washing machine or a dishwasher }\end{array}$ & -0.004 & - & $0.469 * *$ & - \\
\hline $\begin{array}{l}\text { Predicted probability of using water } \\
\text { labelling schemes }\end{array}$ & - & -0.617 & - & -0.072 \\
\hline $\mathrm{N}$ & 9,572 & 973 & 10,305 & 3,904 \\
\hline
\end{tabular}




\section{FACTORS AFFECTING DRINKING HABITS}

\section{Description of the variables of interest}

Respondents were asked which type of 'drinking water' they usually drank. Possible answers included: (1) straight from the tap; (2) purified/filtered/boiled tap water; (3) bottled mainly still/flat; (4) bottled mainly sparkling; (5) natural source (e.g. rainwater, surface water, or well); or (6) other. We build an indicator variable for 'tap water drinkers' that takes the value 1 if respondents drink either water straight from the tap (1) or purified/filtered/boiled water (2). Respondents were also asked how satisfied they were with the 'taste' and the 'health impacts' of their tap water. Answers had to be given on a scale varying from 0 (not satisfied) to 10 (very satisfied).

\section{Methodological issues and approach}

We propose to estimate a Probit model to explain the likelihood of drinking tap water. We expect variables describing respondents' satisfaction about taste and health impacts to be among the most important drivers of households' decision to drink tap water (or not). Opinion variables, when directly related to the variable of interest, are likely to be endogenous: there may exist unobserved characteristics that drive both respondents' perception of health impacts and the decision to drink tap water. If such unobserved variables exist, the coefficients of the opinion variables will be biased. In order to avoid a possible endogeneity bias, we estimate an Instrumental Variables (IV) - Probit model. ${ }^{15}$ Respondents' satisfaction about taste and health impacts are regressed on a set of instruments and their predicted values are then used in the subsequent Probit model describing the likelihood of drinking tap water. Due to the high correlation between the two variables describing satisfaction, we run two separate IV-Probit models (one using 'satisfaction with taste' and the other one using 'satisfaction with health impacts' as explanatory factor).

\section{Main findings}

The full set of estimation results (first-stage instrumental regression and second stage Probit model) is shown in Appendix C (Table C4.1) and the second-stage marginal effects are shown in Table 8. First-stage estimation results show that older respondents, respondents with post high school education and respondents living in town or in a suburban area are more satisfied about taste and health impacts of tap water. Respondents who express a higher environmental concern in general are found to be more satisfied about tap water. However those who are more satisfied with water quality (in their local environment) are also more likely to be satisfied with the quality of tap water. Finally respondents who trusted claims about the environmental impacts of products in general ${ }^{16}$ are more likely to find tap water quality satisfactory.

The instrumented versions of the opinion variables on the taste and health impacts of tap water are used in the second-stage Probit model. As expected, respondents who declared themselves to be more satisfied with their tap water are more likely to drink water from the tap (either straight or purified/filtered/boiled). Older respondents are less likely to drink water from the tap whereas respondents living in town and in suburban areas are more likely to drink tap water. Respondents who in general trust claims on environmental impacts of products are less likely to drink tap water once we control for their

\footnotetext{
${ }^{15}$ Estimated using the ivprobit procedure in Stata.

16 The trust index was built taking into account the five information sources: scientists and experts, national/local governments, environmental non-governmental organisations, consumers' organisations, and manufacturers and retailers.
} 
overall level of satisfaction with water quality. Respondents who express a higher concern about the environment in general are less likely to drink tap water. ${ }^{17}$ Finally, respondents clustered as 'sceptics' are less likely to drink tap water than the reference group of 'environmentally motivated'. ${ }^{18}$

Table 8. Factors affecting the decision to drink tap water

(Probit model estimated marginal effects and statistical significance)

\begin{tabular}{lcc}
\hline & Marginal effect & Marginal effect \\
\hline Variable of interest & Satisfaction with taste & $\begin{array}{c}\text { Satisfaction with health } \\
\text { impacts }\end{array}$ \\
\hline
\end{tabular}

\section{Respondent's level of satisfaction with taste of} tap water (instrumented)

Respondent's level of satisfaction with health impacts of tap water (instrumented)

Age of respondents

Education

(respondent completed at least one year of education after high school $=1$ )

Children

(at least one child under 5 years old $=1$ )

Urban area

(respondent lives in a major town/city or in a

suburban area $=1$ )

Level of trust about claims on the environmental impacts of products

Score on "environmental concern" index

Respondent belongs to the 'environmentally motivated' class (ref)

Respondent belongs to the 'technological optimists' class

Respondent belongs to the 'environmental sceptics' class

$\begin{array}{cc}\mathbf{0 . 1 4 4 * * * *} & \boldsymbol{-} \\ - & \mathbf{0 . 1 5 0} * * * \\ -0.003 * * * & -0.003 * * * \\ 0.004 & 0.006 \\ -0.002 & 0.002 \\ 0.069 * * & 0.081 * * * \\ -0.027 * * * & -0.034 * * * \\ -0.015 & -0.017 * \\ - & - \\ 0.014 & 0.014 \\ -0.067 * * & -0.059 *\end{array}$

${ }^{17}$ The influence of households' perception of the quality of their environment on their drinking decisions was also established in Bontemps and Nauges (2009). In their study of French households' drinking decisions, these authors showed that households who perceived their local environment as degraded were less likely to drink water from the tap.

${ }^{18}$ Three clusters of environmental attitudes were identified in OECD (2014) using the EPIC survey responses to the question on attitudinal statements: 'environmentally motivated', 'environmental sceptics' and 'technological optimists'. 


\section{DISCUSSION AND POLICY IMPLICATIONS}

The analysis of the 2011 OECD household survey on environmental behaviour has shown the importance of pricing policies as well as attitudinal factors in driving households' decisions and behaviours in relation to water use. These findings allow us to derive a number of policy recommendations:

- The results show a consistently significant impact of charging households for water based on their actual consumption. Households which are individually metered and whose bills depend on actual water use are unambiguously more likely to exhibit pro-environmental behaviours in terms of water use. Respondents who declared being charged on the basis of their water use were more likely to 'always' undertake the following four water-conservation behaviours: turning off the water while brushing teeth; plugging the sink when washing dishes by hand; watering garden in the coolest part of the day; and collecting rainwater or recycling wastewater. The effect was positive but not significant as far as taking showers instead of baths is concerned.

- Being charged on the basis of actual water use also increases the likelihood of purchasing watersaving equipment, including low volume or dual flush toilets, water flow restrictor taps/low flow shower heads, and water tank to collect rainwater. It also increases the likelihood that respondents took water efficiency into account at the time of their last purchase of a washing machine or a dishwasher. But the results also showed that the impact of being individually charged for water may differ across countries, possibly because the price of water differs from one country to another.

- Thus, there is an unambiguous effect of individual metering on households' behaviour in terms of water-saving habits and purchase of water-saving equipment. This is not really surprising since we expect, from economics theory, that the price of water sends a signal to the consumers on the value of the 'good'. What we show here is that consumers who receive such a signal through the pricing of their own water use are more likely to be water-conscious than those who do not receive a price signal. To ensure economic efficiency, the price should be set so that it sends a signal on the cost of providing water to the consumers' tap (including scarcity value if water is scarce). The data unfortunately did not allow us to test whether respondents who were charged with a higher volumetric price were more likely to be more water-conscious than those charged with a lower volumetric price.

- One important policy recommendation is that individual metering should be encouraged in old and new apartment buildings and households should be charged based on their actual water use.

- The results confirm previous findings in that the effect of social norms, attitudes, and opinions about the environment in general do matter in explaining households' behaviour and investment decisions. The factors that have the strongest impact are: being a member or supporting an environmental organisation, expressing concern about the environment, and voting in elections. These factors also increase the probability that respondents take water efficiency into account when purchasing either a washing machine or a dishwasher. Some people may be hard to convince but there is likely to be a proportion of the population that can be influenced by campaigns about the state of the environment or/and the role of individuals in protecting the environment. Promoting water-saving behaviours through advertising or/and leaflets is likely to be one of the best way to raise individuals' awareness about environmental issues in general and water issues in particular. Water is a peculiar good in the sense that a significant number of 
people believe that it should be provided for free. So, explaining to customers how much it costs to produce and deliver drinkable water at the tap may help raising awareness about the value of drinkable tap water.

- Gender, age, and household size are respondents/households' characteristics that were found to be the most often significant in explaining behaviour and investment decisions. Female respondents are more likely to undertake water-saving behaviours than male in general (significant for three behaviours out of five). Female respondents were also more likely to have taken water efficiency into account at the time of their last purchase of a washing machine or a dishwasher. Older respondents are more likely to adopt water-conservation behaviours and to purchase water-saving equipment in general, all other things being equal. Larger households also have a higher probability of investing in water-saving devices and to take water efficiency into account. Wealthier households are found to be less likely to undertake water-saving behaviours but we do not find any strong and consistent relationship between income and investment in water-saving equipment.

- These results would call for sensitisation and awareness campaigns to primarily target young men, who seem to be less likely to undertake pro-environmental behaviours. The findings, in particular the non-significance of income, also raise the question of the effectiveness of subsidisation programs (i.e. grants or subsidies that cover part of the investment cost). There exists evidence from the literature that subsidies that promote purchase of (water- or energy-) efficient appliances, either in the form of direct payments, rebates or tax credits, are relatively more effective than price instruments in general (e.g. Jaffe and Stavins, 1995, and Hassett and Metcalf, 1995). However, it is also acknowledged that subsidy programs may induce some freeriding behaviour: households receive rebates to purchase appliances that they would have purchased in the absence of these funds (Hassett and Metcalf, 1995; Grosche and Vance, 2009). In the same line, Weiss et al. (2012) also pointed out a free rider effect in the case of public funding supporting households' pro-environmentally building refurbishment. Another potential issue with subsidy programs is that, by reducing the effective price of energy and water, they create a positive income effect which may altogether increase energy/water use. This counterproductive effect of subsidies is known as the rebound effect in the energy and water literature.

- The same set of factors appears to drive households' water-conservation habits, households' decision to purchase water-saving equipment, and use of water efficiency labels. However we did not find any strong evidence of a direct impact of water efficiency labels on the likelihood of purchasing water-saving equipment. It might reflect the fact that there are a number of households/respondents' characteristics that drive simultaneously their knowledge and use of water efficiency labels, and their decision to purchase water-saving devices. Once these effects are controlled for, there is no additional effect of the label on the investment decision.

- Some specific labels were shown to respondents from three countries only (Australia, Israel, and the Netherlands). A vast majority of the surveyed households were aware of such labels and able to understand them. The lack of variation in knowledge and use of water efficiency labels across households may be one reason for the non-significant effect of labelling on purchase decisions. This question may be worth investigating further but it is important to keep in mind that being aware and using a label is likely to be determined simultaneously with the decision to buy waterefficient devices. An individual willing to purchase a water-efficient washing machine will likely make the effort to learn about and understand water efficiency labelling. 
- The analysis of opinions and drinking behaviour regarding tap water shows that households' demographic characteristics (age, education, and living environment), attitudes and opinions influence respondents' perception of safety and quality aspects of tap water. These findings have to be interpreted with caution since the analysis of perceptions involves psychological factors that are difficult to control for in a regression setting.

- Satisfaction about safety and taste of tap water are strong predictors of the decision to drink tap water. Assessments of safety and taste of tap water are based on perceptions and hence are subjective measures of the true quality of tap water. There are likely unobservable factors driving simultaneously respondents' subjective appraisal of tap water quality and their decision on drinking tap water, which makes the econometric analysis of these questions quite tricky.

- A policy recommendation would thus be to improve households' information about the objective quality of water at the tap. This can be done, for example, by distributing leaflets showing the latest water quality measures.

All in all, the main policy recommendations which can be derived from this study are:

- To generalise individual water metering and to charge households for water based on their actual water use.

- To pursue individuals' sensitisation to environmental issues by promoting water-conservation behaviours through campaigns and advertising, primarily targeting male and young adults.

- To improve households' information about tap water quality.

Based on our findings we would also recommend:

- To further investigate the impact of subsidy programmes to improve their targeting. General subsidy programmes may induce free-riding behaviour.

- To investigate possible rebound effects in water use, i.e. the impact of using water-efficient equipment on household water use.

One of the main caveats of this analysis is the impossibility to control for country-specific water policies that may have been put in place before or in the year the survey took place. The price of water differs from one country to another as well as the type of water-saving policies that have been implemented. In Australia for example, water restrictions are common as well as subsidisation programmes for water-efficient devices. France, on the other hand, has chosen to charge water at a higher price than most of the other countries (Grafton et al., 2011). Being able to control for some of these differences would improve the overall fit of our models and make our estimates more accurate. Hopefully some of these country-specific policies are controlled for through the use of country dummies. Finally, the potential role of subsidisation programs on households' purchase of water-saving equipment could not be addressed in this study for the main reason that only those households who bought such equipment were asked whether they benefited from a subsidy program.

In most cases the results discussed in this report confirm earlier findings, in particular those based on the 2008 OECD household survey (OECD, 2011). First this study confirms the important role of attitudinal variables. Respondents who have expressed a high level of environmental concern, who are members or support environmental organisations, and who voted in past elections are, in almost all cases, more likely to undertake water-saving behaviours and to invest in water-efficient devices. This confirms findings from 
the analysis of the 2008 OECD household survey (OECD, 2011) as well as general results from the academic literature. A perceived environmental threat, such as strong perceptions of the severity of a water shortage, has been found to be closely related to intentions to conserve water by changing behaviour (Kantola, Syme and Nesdale, 1983; Gilg and Barr, 2006; Lam, 2006). Also Gilg and Barr (2006) find that water savers are more likely to perceive an environmental threat whereas non-environmentalists express greater belief in their rights to use water according to their own demand.

The effect of demographics is less clear-cut. Male respondents are found to be less likely to undertake water-saving behaviours. The effect of age is ambiguous but, in most cases, older respondents are found to be more likely to undertake water-saving behaviours and to invest in water-efficient equipment. Education is not found to be significant in general while income was found to have a negative effect on the likelihood to undertake water-saving behaviours. The latter seems to contrast with findings based on the 2008 household survey. The role of demographics in driving households' water conservation behaviour is also ambiguous in the literature: income and education are found to have a positive effect in some studies (e.g. Berk et al., 1993; Renwick and Archibald, 1998, for indoor water-efficient equipment), a negative effect in others (e.g. De Oliver, 1999) or no effect at all (e.g. Lam, 2006; Domene and Sauri, 2006). The impact of income on the adoption of water-efficient equipment is ambiguous ex ante (Hausman, 1979). On the one hand, some equipment entails high investment costs that only richer households may be able to afford, but on the other hand, given the diminishing marginal utility of income, richer households may value savings less than poorer households (Millock and Nauges, 2010). The present study also confirms that household size matters in that larger households are more likely to invest in water-efficient appliances. Household size was not found to be significant in general in models describing the likelihood of undertaking watersaving behaviours.

Finally our results confirm that individual metering of water use has a significant impact on individuals/households' behaviour (both in terms of water-saving behaviours and water-saving equipment), which is in line with findings based on the 2008 OECD household survey (see OECD, 2011; Grafton et al., 2011; Millock and Nauges, 2010). An interesting next step to this study would be testing whether households' behaviour and investment decisions are driven by price levels. It could also be worth investigating the rebound effect, an issue that has not been studied thoroughly in the water literature. We have identified factors driving adoption of water-saving behaviours and purchase of water-saving devices but what matters ultimately is how these decisions impact households' water use. Buying equipment that is more water-efficient makes the cost of water relatively cheaper, which may induce households to increase their water use. These analyses would require information on water use and price at the household level. 


\section{REFERENCES}

Berk, R.A., et al. (1993), "Measuring the impact of water conservation campaigns in California", Climatic Change 24, 233-248.

Bontemps, C. and C. Nauges (2009), "Carafe ou bouteille ? Le rôle de la qualité de l'environnement dans la décision du consommateur", Économie et Prévision, 2009-2, 188, 61-79.

Brown, Z. (2014), "Greening Household Behaviour: Cross-domain comparisons in environmental attitudes and behaviours", OECD Environment Working Papers, No. 68, OECD Publishing, Paris, http://dx.doi.org/10.1787/19970900.

De Oliver, M. (1999), "Attitudes and inaction: a case study of the manifest demographics of urban water conservation”, Environment and Behavior 31, 372-394.

Domene, E. and D. Sauri (2006), "Urbanisation and water consumption: Influencing factors in the metropolitan region of Barcelona", Urban Studies 43(9), 1605-1623.

Ehreke I., B. Jaeggi and K. W. Axhausen (2014), "Greening Household Behaviour and Transport”, OECD Environment Working Papers, OECD Publishing, Paris, http://dx.doi.org/10.1787/19970900.

Gilg, A. and S. Barr (2006), "Behavioural attitudes towards water saving? Evidence from a study of environmental actions”, Ecological Economics 57(3), 400-414.

Grafton, R.Q., et al. (2011), "Determinants of residential water consumption: Evidence and analysis from a 10-country household survey", Water Resources Research 47, W08537, 14 pp., doi: 10.1029/2010WR009685

Grosche, P., and C. Vance (2009), "Willingness-to-pay for energy conservation and free-ridership on subsidization: evidence from Germany”, Energy Journal 30, 135-154.

Hassett, K.A. and G.E. Metcalf (1995), "Energy tax credits and residential conservation investment: evidence from panel data", Journal of Public Economics 57, 201-217.

Hausman, J. (1979), "Individual discount rates and the purchase and utilization of energy-using durables", The Bell Journal of Economics 10, 33-54.

Jaffe, A.B. and R. N. Stavins (1995), "Dynamic incentives of environmental regulations: the effects of alternative policy instruments on technology diffusion", Journal of Environmental Economics and Management 29, S43-S63.

Kantola, S.J., G. J. Syme, A. R. Nesdale (1983), "The effects of appraised severity and efficacy in promoting water conservation: An informational analysis", Journal of Applied Social Psychology 13(2), 164-182. 
Kriström B. and C. Kiran (2014), "Greening Household Behaviour and Energy", OECD Environment Working Papers, OECD Publishing, Paris, http://dx.doi.org/10.1787/19970900.

Lam, S.P. (2006), "Predicting intention to save water: Theory of planned behavior, response efficacy, vulnerability, and perceived efficiency of alternative solutions", Journal of Applied Social Psychology 36(11), 2803-2824.

Millock, K. (2014), “Greening Household Behaviour and Food”, OECD Environment Working Papers, No. 75, OECD Publishing, Paris, http://dx.doi.org/10.1787/19970900.

Millock, K. and C. Nauges (2010), "Household adoption of water-efficient equipment: The role of socialeconomic factors, environmental attitudes and policy", Environmental and Resource Economics 46(4), 539-565.

OECD (2014), Greening Household Behaviour: Overview from the 2011 Survey - Revised edition, OECD Studies on Environmental Policy and Household Behaviour, OECD Publishing, Paris, http://dx.doi.org/10.1787/9789264214651-en.

OECD (2011), Greening Household Behaviour: The Role of Public Policy, OECD Studies on Environmental Policy and Household Behaviour, OECD Publishing, Paris, http://dx.doi.org/10.1787/9789264096875-en.

Palatnik R.R. et al. (2014), "Greening Household Behaviour and Waste”, OECD Environment Working Papers, OECD Publishing, Paris, http://dx.doi.org/10.1787/19970900.

Renwick, M.E. and S.O. Archibald (1998), "Demand side management policies for residential water use", Land Economics 74(3), 343-359.

Serret Y. and Z. Brown (2014), "Greening household behaviour: Overview of results from econometric analysis and policy implications", OECD Environment Working Papers, OECD Publishing, Paris, http://dx.doi.org/10.1787/19970900.

Van de Ven, W.P.M.M. and B.M.S. Van Pragg (1981), "The demand for deductibles in private health insurance: A probit model with sample selection”, Journal of Econometrics 17, 229-252.

Weiss, J., E. Dunkelberg, T. Vogelpohl (2012), "Improving policy instruments to better tap into homeowner refurbishment potential: Lessons learned from a case study in Germany", Energy Policy 44, 406-415. 
ENV/WKP(2014)11

ANNEX 1: FACTORS INFLUENCING WATER-SAVING BEHAVIOUR: MAIN RESULTS FROM PREVIOUS STUDIES

\begin{tabular}{|c|c|c|c|c|c|c|c|}
\hline & Education & Income & Ownership & Perception of environmental threat & $\begin{array}{l}\text { Member of } \\
\text { env. org. }\end{array}$ & Metering & Country \\
\hline Berk et al. (1993) & + & + & + & & & & US (California) \\
\hline Renwick and Archibald (1998) & & $\begin{array}{l}+ \text { (indoor) } \\
\text { - (outdoor) }\end{array}$ & $\begin{array}{c}\text { - (indoor) } \\
\text { n.s. (outdoor) }\end{array}$ & & & & US (California) \\
\hline De Oliver (1999) & - & - & & & & & US (Texas) \\
\hline Domene and Sauri (2006) & & n.s. & & & & & Spain \\
\hline Gilg and Barr (2006) & + & & + & + & + & & England \\
\hline Lam (2006) & + and n.s. & & & + & & & $\begin{array}{l}\text { Chinese Taipei } \\
\text { (two samples) }\end{array}$ \\
\hline \multicolumn{8}{|l|}{ OECD 2008} \\
\hline Millock and Nauges (2010) & & $\begin{array}{l}+ \text { (indoor) } \\
- \text { (outdoor) }\end{array}$ & + & + & + & + & OECD 10 \\
\hline Grafton et al. (2011) & + and - & - & & & + & + & OECD 10 \\
\hline
\end{tabular}


ENV/WKP(2014)11

\section{ANNEX 2: DATA SOURCES AND LIMITATIONS}

Based on a sample of more than 12000 respondents in eleven countries, ${ }^{19}$ this thematic report summarises main results on energy from the 2011 OECD periodic surveys on Environmental Policy and Individual Behaviour Change (EPIC) and draws evidence-based policy recommendations. ${ }^{20}$ It builds on earlier work and supplements the overview of the 2011 survey data presented in OECD (2014). ${ }^{21}$

As in all studies involving primary data collection, there can be a sample bias when implementing a survey. Rigorous efforts were made at stratification and quota sampling. The sampling strategy involved stratification across region, gender, age and socio-economic status. The degree to which the country-level samples are representative of the national population is presented for a number of key variables in OECD (2014) in Annex B. However, in some countries (e.g. Chile and Switzerland) not all of these parameters could be included. Nonetheless, as Annex B in OECD (2014) shows, deviations in excess of 20 per cent from representativity across these variables, for which quotas were set, were very limited. Response bias can be a second concern. It should be noted that such a bias is not specific to using internet panel-based surveys and responses can be biased by the interviewer in face-to-face interviews and telephone surveys. Given that the subject matter of the OECD survey is not related to information technologies or Internet, except for a very small number of questions (i.e. investment in "smart" meters), there is little reason to believe that this would result in a systematic bias.

It is also important for the reader to bear in mind the fact that all of the data used in the analyses reported here are based upon survey responses. This survey elicited respondents' stated preferences and perceptions. Therefore statistics reported here which relate to objective, verifiable indicators should be interpreted with caution and in some cases there may be 'measurement error'. On the one hand, this may relate to the dependent variable used in the studies. For example, estimates of waste generation and recycling rates may be inexact for some respondents. Similarly, estimates of the percentage of fresh fruit and vegetables consumed which is organic may also be inexact. On the other hand, some respondents may be mistaken about the precise nature of the policy measures to which they are subject. For example, it is possible that some respondents may not be aware that a given policy exists in their country. Similarly, some respondents may mistakenly believe that a policy exists in their country, when in fact it does not. However, it is important to note that for all questions in which there was significant potential for such "measurement error", respondents were given the option to respond that they "did not know" if such a policy was in place. This may relate to both "carrot" (i.e. grants for investment in energy-efficient devices, scrappage bounties for motor vehicles) and "stick" approaches (i.e. price-based measures). Given the large sample size, such observations should not affect the results in an important way. However, in order to ensure robustness of the results, a large number of models were estimated, including models with different country samples. Attention is drawn to important differences.

In general, readers should view these data as exactly what they are: the self-reported behaviours, attitudes and perceptions of representative samples of households from eleven OECD countries. Bearing the limits of such data in mind, it is important to recognise their advantages: information on households' knowledge and perceptions about environmental issues - increasingly recognised as a crucial factor for better understanding behavioural responses to environmental policies - is rarely analysed at such level of detail. Moreover, for many variables such as discrete choices about whether or not a given purchase has been made, there is likely to be very little deviation from a more formal household consumer survey.

\footnotetext{
19 Australia, Canada, Chile, France, Israel, Japan, Korea, the Netherlands, Spain, Sweden and Switzerland. Approximately 1000 households were surveyed in each country.

${ }^{20}$ The first survey was carried out in 2008 in ten countries with a sample of more than 11000 respondents and the main results were presented in the OECD (2011).

${ }^{21}$ The full 2011 EPIC Survey questionnaire in English is provided in OECD (2014) in Annex A.
} 


\section{APPENDIX A: PROBIT MODEL WITH SAMPLE SELECTION}

This description is taken from Van de Ven and Van Pragg (1981) and Stata documentation.

The probit model with sample selection assumes that there exists an underlying (linear) relationship between a latent variable $y^{*}$ and some exogenous factors gathered in vector $\mathbf{x}$ :

$$
y^{*}=\mathbf{x}^{\prime} \boldsymbol{\beta}+v_{1}
$$

where $\boldsymbol{\beta}$ is a set of unknown parameters and $v_{1}$ is an error term which is assumed distributed following a standard normal distribution (i.e. it is assumed of mean 0 and variance 1 ). We do not observe the latent variable $y^{*}$, only the decision (or binary outcome):

$$
y^{\text {probit }}=\left(y^{*}>0\right) \text {, i.e. } y^{\text {probit }}=\left\{\begin{array}{l}
1 \text { if } y^{*}>0 \\
0 \text { if not }
\end{array} .\right.
$$

In the case of water-efficient equipment for example, $y^{*}$ could be seen as the difference between the household's expected utility with adoption and expected utility without adoption of the equipment. If the difference is positive $\left(y^{*}>0\right)$, then the household will purchase the equipment and the variable $y^{\text {probit }}$ will take the value 1 .

If the decision is not always observed (for example because households are renters and do not have the possibility to purchase water-saving equipment), we have to specify a selection equation that describes the probability of $y^{\text {probit }}$ being observed:

$$
y^{\text {select }}=\left(\mathbf{z}^{\prime} \gamma+v_{2}>0\right)
$$

where $\mathbf{z}$ is a vector of exogenous factors explaining why $y^{\text {probit }}$ is observed, $\boldsymbol{\gamma}$ is the vector of unknown parameters, and $v_{2}$ is an error term which is assumed distributed following a standard normal distribution. If possible, it is better (for identification purposes) to include in $\mathbf{z}$ one or more variables that are not in $\mathbf{x}$ (such variables would be called 'excluded instruments').

We denote by $\rho$ the correlation coefficient between the error terms $\left(v_{1}\right.$ and $\left.v_{2}\right)$ in the two equations. If $\rho$ is different from zero, there exists unobservable variables that explain simultaneously selection into the sample and the binary decision of interest. In such a case the estimation of a simple Probit would produce biased estimates of the $\boldsymbol{\beta}$ parameters. In order to obtain consistent estimates the selection equation has to be estimated with the equation of interest. Under the assumption that the error terms are normally distributed, the Maximum Likelihood estimator produces unbiased coefficients. 
ENV/WKP(2014)11

\section{APPENDIX B: LIST AND DEFINITION OF THE VARIABLES USED IN THE REPORT}

\section{Demographics}

\begin{tabular}{|c|c|}
\hline age & Age of the respondent (in years); from question A2. \\
\hline a3_hhsize & Number of people in the household; from question A3. \\
\hline a12_residsize & Size of residence (in $\mathrm{m}^{2}$ ); from question $\mathrm{A} 12$ \\
\hline employed & $\begin{array}{l}\text { Dummy }=1 \text { if the respondent is an employee or self-employed, } \\
=0 \text { otherwise; from question A6. }\end{array}$ \\
\hline male & $\begin{array}{l}\text { Dummy }=1 \text { if the respondent is a male, }=0 \text { otherwise; from } \\
\text { question A1. }\end{array}$ \\
\hline posthighschool & $\begin{array}{l}\text { Dummy = } 1 \text { if the respondent completed at least one year of } \\
\text { education after high school, = } 0 \text { otherwise; from question A5. }\end{array}$ \\
\hline _owner & $\begin{array}{l}\text { Dummy = } 1 \text { if the respondent (or/and another member of } \\
\text { his/her household) is the owner of the residence, }=0 \\
\text { otherwise; from question A } 10 \text {. }\end{array}$ \\
\hline i_town & $\begin{array}{l}\text { Dummy }=1 \text { if the respondent lives in a major town/city or in a } \\
\text { suburban area, = } 0 \text { otherwise; from question A } 13 \text {. }\end{array}$ \\
\hline i_under5 & $\begin{array}{l}\text { Dummy = } 1 \text { if there is at least one child under } 5 \text { years old in the } \\
\text { household, = } 0 \text { otherwise; from question A3. }\end{array}$ \\
\hline log_income $(\log I N C)$ & $\begin{array}{l}\text { Log of household's annual income after tax (thousands of } \\
\text { EUR/year); from question A8. }\end{array}$ \\
\hline
\end{tabular}

Attitudes, behaviours, and opinions
b3_envconcern_index Index that reflects concern about environmental issues in general, a higher value means more concern about the environment; from question B3.
b4_vote
Dummy $=1$ if the respondent had voted in local or national elections in the past six years, $=0$ otherwise; from question B4.
b5_envorg_support Dummy $=1$ if the respondent has supported or participated in activities of an environmental organisation in the past two years, $=0$ otherwise; from question B5.
b6_env_att2
Ordinal variable (2: strongly disagree; 1 : disagree; 0 : no opinion; -1: agree; -2 : strongly agree) describing opinion of respondents on the statement 'Environmental impacts are frequently overstated.'
b6_env_att6
Ordinal variable (2: strongly disagree; 1 : disagree; 0 : no opinion; -1: agree; -2: strongly agree) describing opinion of respondents on the statement 'Environmental issues will be resolved in any case through technological progress.'
b6_envmotivated
Dummy $=1$ if the respondent belongs to the 'environmentally motivated' class, $=0$ otherwise; from question B6.
b6_technoptimists
b6_sceptics
Dummy $=1$ if the respondent belongs to the 'technological optimists' class, $=0$ otherwise; from question B6.
Dummy $=1$ if the respondent belong to the 'environmental sceptics' class, $=0$ otherwise; from question B6.


ENV/WKP(2014)11

b7_trust_index Index that reflects general level of trust about the environmental impacts of products (from all sources of information), a higher value means a higher level of trust; from question B7.

b8_locenv_water Index that reflects the respondent's level of satisfaction with respect to water quality, a higher value means a greater level of satisfaction; from question B8.

health_satis Index that reflects the level of satisfaction with the health impacts of tap water, a higher values means a greater level of satisfaction; from question G8.

i_recycle_glass Dummy $=1$ if the respondent/household recycles $100 \%$ of the glass bottles/containers, $=0$ otherwise; from question $\mathrm{C} 4$.

taste_satis Index that reflects the level of satisfaction with the taste of tap water, a higher values means a greater level of satisfaction; from question G8.

\section{Policy variables}

g3_watereff

Dummy $=1$ if the respondent took water efficiency into account when he/she last purchased either a washing machine or a dishwasher, $=0$ otherwise; from question G3.

label_watereff Dummy $=1$ if the respondent is using the water efficiency label that was displayed at the time of the survey, $=0$ otherwise; from question L4 (only for Australia, Israel, and the Netherlands).

unitcharge Dummy $=1$ if water is charged based on the volume of water use, $=0$ otherwise; from question G1.

unitcharge (do not know)

Dummy $=1$ if the respondent does not know if water is charged based on the volume of water use, $=0$ otherwise; from question G1. 


\section{APPENDIX C: FULL SET OF ESTIMATION RESULTS}

\section{C1. Adoption of water-saving behaviours - Estimation results}

We report below estimated coefficients and significance levels for the five Probit models describing adoption of water-saving behaviours. Sample selection bias is controlled for in the third and fourth models by estimating a selection equation. Excluded instruments are respondents' employment status, household size, urban versus rural location, and glass recycling practices. Weights are taken into account and robust standard errors are calculated.

Table C1. Likelihood to always undertake water-saving behaviours

(Probit model estimated coefficients and statistical significance)

\begin{tabular}{|c|c|c|c|c|c|}
\hline & Beh. $1^{\text {(a) }}$ & Beh. 2 & Beh. 3 & Beh. 4 & Beh. 5 \\
\hline Unit water charge & $0.124 * *$ & $0.144 * * *$ & $0.218 * * *$ & $0.142 * *$ & 0.036 \\
\hline Unit water charge (do not know) & $-0.239 * *$ & -0.048 & -0.069 & 0.036 & -0.105 \\
\hline Gender $($ male $=1)$ & $-0.152 * * *$ & 0.021 & $-0.173 * * *$ & $-0.114 * *$ & 0.028 \\
\hline Age of respondents & $-0.004 * *$ & $0.005 * * *$ & $0.008 * * *$ & $0.006 * * *$ & -0.001 \\
\hline $\begin{array}{l}\text { Education } \\
\text { (respondent completed at least one year of education } \\
\text { after high school =1) }\end{array}$ & -0.066 & -0.043 & 0.087 & -0.073 & 0.035 \\
\hline $\log \mathrm{INC}$ & $-0.071 *$ & -0.030 & -0.027 & $-0.113 * *$ & $-0.121 * * *$ \\
\hline $\begin{array}{l}\text { Ownership status } \\
\text { (ownership of the residence }=1 \text { ) }\end{array}$ & $0.088^{*}$ & 0.053 & $-0.124 *$ & -0.109 & $-0.153 * * *$ \\
\hline Score on "environmental concern" index & $0.082 * * *$ & $0.048 * * *$ & $0.128 * * *$ & $0.096 * * *$ & $0.042 * *$ \\
\hline Supporting environmental organisation & $0.232 * * *$ & $0.175 * * *$ & $0.158 * *$ & $0.156^{*}$ & -0.032 \\
\hline $\begin{array}{l}\text { Voting } \\
\text { (voted in local or national } \\
\text { elections in the past six years }=1 \text { ) }\end{array}$ & $0.120 * *$ & $0.163 * * *$ & 0.048 & $0.128^{*}$ & $-0.172 * *$ \\
\hline $\begin{array}{l}\text { Disagreement with the statement "environmental } \\
\text { impacts are frequently overstated" }\end{array}$ & $-0.035^{*}$ & 0.028 & 0.013 & $0.035^{*}$ & 0.015 \\
\hline $\begin{array}{l}\text { Disagreement with the statement "environmental } \\
\text { issues will be resolved in any case through } \\
\text { technological progress" }\end{array}$ & $0.033^{*}$ & -0.017 & 0.003 & 0.001 & -0.006 \\
\hline Australia (reference) & - & - & - & - & - \\
\hline Canada & $-0.396 * * *$ & $-0.258 * * *$ & $-0.413 * * *$ & $-0.647 * * *$ & $-0.568 * * *$ \\
\hline Chile & $-0.692 * * *$ & $-1.383 * * *$ & $-0.286^{* *}$ & $-1.383 * * *$ & $-0.616^{* * *}$ \\
\hline France & 0.005 & $-0.588 * * *$ & $-0.181 * * *$ & $-0.135^{* *}$ & $-0.275^{* * *}$ \\
\hline Israel & $-0.151 * *$ & $-1.861 * * *$ & $-0.373 * * *$ & $-0.969 * * *$ & $-0.218 * *$ \\
\hline Japan & -0.046 & $-1.629 * * *$ & $-1.436 * * *$ & $-0.908 * * *$ & $-2.216 * * *$ \\
\hline Korea & $-0.329 * * *$ & $-1.736^{* * *}$ & $-1.801 * * *$ & $-1.256^{* * *}$ & $-0.704 * * *$ \\
\hline The Netherlands & $-0.403 * * *$ & $-0.272 * * *$ & $-0.470 * * *$ & $-0.577 * * *$ & $-0.664 * * *$ \\
\hline Spain & -0.012 & $-1.057 * * *$ & $-0.406 * * *$ & $-0.937 * * *$ & 0.049 \\
\hline
\end{tabular}




\section{ENV/WKP(2014)11}

\begin{tabular}{|c|c|c|c|c|c|}
\hline Sweden & $-0.605 * * *$ & $-0.714 * * *$ & $-0.754 * * *$ & $-0.700 * * *$ & $-0.483 * * *$ \\
\hline Switzerland & $-0.201 * * *$ & $-1.012 * * *$ & $-0.632 * * *$ & $-0.480 * * *$ & $-0.735 * * *$ \\
\hline constant & $0.693 *$ & 0.036 & -0.289 & 0.360 & $2.236 * * *$ \\
\hline \multicolumn{6}{|l|}{ Selection equation } \\
\hline $\begin{array}{l}\text { Employee status } \\
\text { (the respondent is an employee or self-employed }=1 \text { ) }\end{array}$ & - & - & 0.046 & 0.082 & - \\
\hline Age of respondents & - & - & $0.010 * * *$ & 0.000 & - \\
\hline Household size & - & - & $0.093 * * *$ & - & - \\
\hline $\begin{array}{l}\text { Ownership status } \\
\text { (ownership of the residence }=1 \text { ) }\end{array}$ & - & - & $0.387 * * *$ & $0.493 * * *$ & - \\
\hline $\operatorname{logINC}$ & - & - & -0.005 & 0.018 & - \\
\hline $\begin{array}{l}\text { Urban area } \\
\text { (respondent lives in a major town/city or in a } \\
\text { suburban area }=1 \text { ) }\end{array}$ & - & - & $-0.166 * * *$ & $-0.317 * * *$ & - \\
\hline $\begin{array}{l}\text { Recycling } \\
\text { (household recycles } 100 \% \text { of the glass } \\
\text { bottles/containers }=1 \text { ) }\end{array}$ & - & - & - & -0.025 & - \\
\hline constant & - & - & -0.401 & 0.269 & - \\
\hline \multicolumn{6}{|l|}{ Statistics } \\
\hline $\mathrm{N}$ & 10,232 & 9,672 & 10,314 & 10,310 & 10,059 \\
\hline chi2 & 377.3 & 1281.7 & 305.5 & 226.0 & 1256.0 \\
\hline $\mathrm{p}$ & 0.000 & 0.000 & 0.000 & 0.000 & 0.000 \\
\hline Wald test of $\rho=0$; $\operatorname{chi} 2(1)$ & - & - & 9.50 & 8.38 & - \\
\hline Prob > chi2 & - & - & 0.002 & 0.004 & - \\
\hline
\end{tabular}

(a) Behaviour 1: Always turning off the water while brushing teeth;

Behaviour 2: Always plugging the sink when washing dishes by hand;

Behaviour 3: Always watering garden in the coolest part of the day;

Behaviour 4: Always collecting rainwater or recycling wastewater;

Behaviour 5: Always taking showers instead of baths.

${ }^{* * *} p<0.01,{ }^{* *} p<0.05,{ }^{*} p<0.1$ 


\section{C2. Investment in water-efficient devices - Estimation results}

We report below estimated coefficients and significance levels for the three Probit models describing purchase of water-efficient devices. Sample selection bias is controlled for by estimating a selection equation. Excluded instruments are ownership status, urban versus rural location, and glass recycling habits. Weights are taken into account and robust standard errors are calculated.

\section{Table C2. Likelihood to purchase water-saving devices}

(Probit model estimated coefficients and statistical significance)

\begin{tabular}{|c|c|c|c|}
\hline & $\begin{array}{c}\text { Water flow restrictor } \\
\text { taps/low flow shower } \\
\text { heads }\end{array}$ & $\begin{array}{l}\text { Low-volume or } \\
\text { dual flush toilets }\end{array}$ & Water tanks \\
\hline Unit water charge & $0.138 * *$ & $0.138 * *$ & $0.186^{* * *}$ \\
\hline Unit water charge (do not know) & -0.186 & 0.030 & 0.083 \\
\hline Gender $($ male $=1)$ & 0.043 & 0.067 & -0.005 \\
\hline Age of respondents & $0.007 * * *$ & $0.007 * * *$ & 0.002 \\
\hline Household size & $0.053 * * *$ & $0.057 * * *$ & $0.034 *$ \\
\hline $\operatorname{logINC}$ & 0.036 & 0.030 & $-0.120 * *$ \\
\hline Score on "environmental concern" index & $0.065 * * *$ & 0.017 & $0.047 * *$ \\
\hline Supporting environmental organisation & $0.260 * * *$ & $0.369 * * *$ & $0.319 * * *$ \\
\hline $\begin{array}{l}\text { Voting } \\
\text { (voted in local or national } \\
\text { elections in the past six years }=1 \text { ) }\end{array}$ & $0.239 * * *$ & $0.149 * *$ & $0.239 * * *$ \\
\hline $\begin{array}{l}\text { Disagreement with the statement "environmental } \\
\text { impacts are frequently overstated" }\end{array}$ & $-0.034 *$ & -0.028 & 0.017 \\
\hline $\begin{array}{l}\text { Disagreement with the statement "environmental } \\
\text { issues will be resolved in any case through } \\
\text { technological progress" }\end{array}$ & 0.008 & -0.018 & -0.010 \\
\hline Australia (reference) & - & - & - \\
\hline Canada & $-0.357 * * *$ & $-0.716^{* * *}$ & $-0.544 * * *$ \\
\hline Chile & $-0.635 * * *$ & $-1.059 * * *$ & $-1.420 * * *$ \\
\hline France & $-0.580 * * *$ & $-0.211 * * *$ & -0.019 \\
\hline Israel & -0.136 & -0.032 & $-1.015 * * *$ \\
\hline Japan & $-1.382 * * *$ & $-1.468 * * *$ & $-1.395^{* * *}$ \\
\hline Korea & $-0.838 * * *$ & $-1.418 * * *$ & $-1.370 * * *$ \\
\hline The Netherlands & 0.016 & $-0.297 * * *$ & $-0.594 * * *$ \\
\hline Spain & $-0.389 * * *$ & $-0.511 * * *$ & $-1.144 * * *$ \\
\hline Sweden & $-0.593 * * *$ & $-0.621 * * *$ & $-0.792 * * *$ \\
\hline Switzerland & $-0.452 * * *$ & $-0.752 * * *$ & $-0.501 * * *$ \\
\hline constant & $-1.139 * *$ & -0.360 & 0.384 \\
\hline
\end{tabular}

Selection equation 


\section{ENV/WKP(2014)11}

Age of respondents

Ownership status

(ownership of the residence $=1$ )

$\log$ INC

Urban area

(respondent lives in a major town/city or in a suburban area $=1$ )

Recycling

(household recycles $100 \%$ of the glass

bottles/containers $=1$ )

constant

Statistics

$\mathrm{N}$

chi2

$\mathrm{p}$

Wald test of $\rho=0$; $\operatorname{chi} 2(1)$

Prob > chi2

$\begin{array}{cc}0.007 * * * & 0.000 \\ 0.811^{* * * *} & 0.767 * * * \\ 0.101 * * * & 0.118 * * * \\ -0.050 & -0.312 * * * \\ & \\ -0.146 * * * & -0.198 * * * \\ -1.174 * * * & -0.893 * * *\end{array}$

8126

10305

10303

573.5

476.1

347.0

0.000

0.000

0.000

29.40

37.05

0.000

0.000

${ }^{* \star *} p<0.01,{ }^{* *} p<0.05,{ }^{*} p<0.1$ 
C3. The role of water efficiency labels - Estimation results

Table C3.1. Likelihood of taking water-efficiency into account

(Probit model estimated coefficients and statistical significance)

\begin{tabular}{|c|c|}
\hline & Coef. \\
\hline Unit water charge & $0.127^{* *}$ \\
\hline Unit water charge (do not know) & $-0.306 * * *$ \\
\hline Gender $($ male $=1)$ & $-0.186^{* * *}$ \\
\hline Age of respondents & 0.003 \\
\hline Household size & $0.081^{* * *}$ \\
\hline Education (respondent completed at least one year of education after high school =1) & -0.037 \\
\hline Score on "environmental concern" index & $0.110 * * *$ \\
\hline Supporting environmental organisation & $0.423 * * *$ \\
\hline Voting (voted in local or national elections in the past six years $=1$ ) & $0.284 * * *$ \\
\hline $\begin{array}{l}\text { Disagreement with the statement "environmental issues will be resolved in any case through } \\
\text { technological progress" }\end{array}$ & -0.014 \\
\hline Disagreement with the statement "environmental impacts are frequently overstated" & 0.014 \\
\hline \multicolumn{2}{|l|}{ Australia (reference) } \\
\hline Canada & $-0.286 * * *$ \\
\hline Chile & $-1.015^{* * *}$ \\
\hline France & $-0.165^{* *}$ \\
\hline Israel & $-0.721 * * *$ \\
\hline Japan & $-0.863 * * *$ \\
\hline Korea & $-0.870 * * *$ \\
\hline The Netherlands & $-0.334 * * *$ \\
\hline Spain & $-0.417 * * *$ \\
\hline Sweden & $-0.724 * * *$ \\
\hline Switzerland & $-0.181 * *$ \\
\hline constant & -0.317 \\
\hline \multicolumn{2}{|l|}{ Selection equation } \\
\hline Age of respondents & $0.009^{* * *}$ \\
\hline Ownership status (ownership of the residence $=1$ ) & $0.390 * * *$ \\
\hline Recycling (household recycles $100 \%$ of the glass bottles/containers $=1$ ) & $0.235^{* * *}$ \\
\hline constant & $-0.130^{*}$ \\
\hline $\mathrm{N}$ & 12,181 \\
\hline $\operatorname{chi} 2(\mathrm{p})$ & $228.5(0.000)$ \\
\hline Wald test of $\rho=0 ; \operatorname{chi} 2(1)$ & 7.58 \\
\hline Prob > chi2 & 0.006 \\
\hline
\end{tabular}


Table C3.2. Likelihood of using water efficiency labels (Australia, Israel, and the Netherlands)

(Probit model estimated coefficients and statistical significance)

\begin{tabular}{|c|c|}
\hline & Coef. \\
\hline Unit water charge & $0.377 * * *$ \\
\hline Unit water charge (do not know) & -0.203 \\
\hline Gender $($ male $=1)$ & $-0.230 * *$ \\
\hline Age of respondents & 0.001 \\
\hline $\begin{array}{l}\text { Education } \\
\text { (respondent completed at least one year of education after high school = } \\
\text { 1) }\end{array}$ & -0.146 \\
\hline $\log \mathrm{INC}$ & 0.132 \\
\hline Score on "environmental concern" index & $0.129 * * *$ \\
\hline Supporting environmental organisation & $0.286^{*}$ \\
\hline $\begin{array}{l}\text { Voting } \\
\text { (voted in local or national } \\
\text { elections in the past six years }=1 \text { ) }\end{array}$ & 0.225 \\
\hline $\begin{array}{l}\text { Disagreement with the statement "environmental impacts are frequently } \\
\text { overstated" }\end{array}$ & $-0.080 *$ \\
\hline $\begin{array}{l}\text { Disagreement with the statement "environmental issues will be resolved } \\
\text { in any case through technological progress" }\end{array}$ & 0.063 \\
\hline Australia (reference) & - \\
\hline Israel & $-1.034 * * *$ \\
\hline The Netherlands & $-1.113^{* * *}$ \\
\hline constant & -1.455 \\
\hline $\mathrm{N}$ & 1,250 \\
\hline chi2 & 188.9 \\
\hline $\mathrm{p}$ & 0.000 \\
\hline
\end{tabular}

${ }^{* * *} p<0.01,{ }^{* *} p<0.05,{ }^{*} p<0.1$ 
ENV/WKP(2014)11

Table C3.3. The role of water efficiency labels in driving adoption of water-efficient devices

(Probit model estimated coefficients and statistical significance)

\begin{tabular}{|c|c|c|c|c|}
\hline \multirow{2}{*}{$\begin{array}{l}\text { Dependent variable } \\
\text { Label variable }\end{array}$} & \multicolumn{2}{|c|}{$\begin{array}{l}\text { Adoption of water-flow restrictor } \\
\text { taps/low flow shower heads }\end{array}$} & \multicolumn{2}{|c|}{$\begin{array}{l}\text { Adoption of low volume or } \\
\text { dual flush toilet }\end{array}$} \\
\hline & $\begin{array}{r}\text { label considered } \\
\text { at latest } \\
\text { purchase }\end{array}$ & $\begin{array}{r}\text { using water } \\
\text { labelling } \\
\text { schemes }\end{array}$ & $\begin{array}{r}\text { label } \\
\text { considered at } \\
\text { latest } \\
\text { purchase }\end{array}$ & $\begin{array}{r}\text { using water } \\
\text { labelling } \\
\text { schemes }\end{array}$ \\
\hline Unit water charge & $0.150 * *$ & 0.291 & 0.093 & $0.353^{*}$ \\
\hline Unit water charge (do not know) & -0.204 & -0.079 & 0.153 & 0.456 \\
\hline Gender $($ male $=1)$ & 0.018 & -0.072 & $0.137 * *$ & 0.158 \\
\hline Age of respondents & $0.008 * * *$ & $0.013 * * *$ & $0.006 * * *$ & $0.019 * * *$ \\
\hline Household size & $0.063 * *$ & $0.089 * *$ & 0.026 & 0.054 \\
\hline $\begin{array}{l}\text { Education } \\
\text { (respondent completed at least one year of education } \\
\text { after high school = 1) }\end{array}$ & -0.087 & 0.023 & - & - \\
\hline $\log \mathrm{INC}$ & - & - & 0.035 & -0.172 \\
\hline Score on "environmental concern" index & $0.066^{*}$ & $0.165 * * *$ & -0.026 & 0.079 \\
\hline Supporting environmental organisation & $0.189 *$ & $0.393 * *$ & - & - \\
\hline $\begin{array}{l}\text { Voting } \\
\text { (voted in local or national } \\
\text { elections in the past six years }=1 \text { ) }\end{array}$ & $0.261 * *$ & 0.263 & $0.243 * *$ & 0.131 \\
\hline $\begin{array}{l}\text { Disagreement with the statement "environmental } \\
\text { impacts are frequently overstated" }\end{array}$ & -0.030 & -0.002 & -0.023 & 0.010 \\
\hline $\begin{array}{l}\text { Disagreement with the statement "environmental } \\
\text { issues will be resolved in any case through } \\
\text { technological progress" }\end{array}$ & 0.015 & $0.104 *$ & -0.024 & 0.012 \\
\hline $\begin{array}{l}\text { Predicted probability of considering water- } \\
\text { efficiency label when last purchasing a washing } \\
\text { machine or a dishwasher }\end{array}$ & -0.010 & - & $1.178 * *$ & - \\
\hline $\begin{array}{l}\text { Predicted probability of using water labelling } \\
\text { schemes }\end{array}$ & - & -1.839 & - & -0.681 \\
\hline Australia (reference) & - & - & - & - \\
\hline Canada & $-0.317 * * *$ & - & $-0.631 * * *$ & - \\
\hline Chile & $-0.687 * *$ & - & $-0.694 * * *$ & - \\
\hline France & $-0.591 * * *$ & - & $-0.159 * *$ & - \\
\hline Israel & -0.150 & -0.703 & 0.223 & -0.250 \\
\hline Japan & $-1.335 * * *$ & - & $-1.157 * * *$ & - \\
\hline Korea & $-0.866 * * *$ & - & $-1.107 * * *$ & - \\
\hline The Netherlands & -0.004 & -0.500 & $-0.191 * *$ & -0.569 \\
\hline Spain & $-0.411 * * *$ & - & $-0.374 * * *$ & - \\
\hline Sweden & $-0.563 * *$ & - & $-0.362 * * *$ & - \\
\hline Switzerland & $-0.386 * * *$ & - & $-0.701 * * *$ & - \\
\hline constant & $-0.728 *$ & -0.403 & -0.839 & 2.085 \\
\hline
\end{tabular}




\section{ENV/WKP(2014)11}

\section{Selection equation}

Age of respondents

Ownership status

(ownership of the residence $=1$ )

$\log \mathrm{INC}$

Urban area

(respondent lives in a major town/city or in a suburban area $=1$ )

\section{Recycling}

(household recycles $100 \%$ of the glass

bottles/containers $=1$ )

constant

9,572

973

Wald test of $\rho=0$; $\operatorname{chi} 2(1)$ 
ENV/WKP(2014)11

C4. Drinking tap water - Estimation results

Table C4.1. Decision to drink tap water

(Instrumental Variables Probit model, estimation results)

\begin{tabular}{|c|c|c|}
\hline & Coef. & Coef. \\
\hline Variable of interest & $\begin{array}{r}\text { Satisfaction with } \\
\text { taste } \\
\end{array}$ & $\begin{array}{r}\text { Satisfaction with } \\
\text { health impacts }\end{array}$ \\
\hline Respondent's level of satisfaction with taste of tap water (instrumented) & $0.144 * * *$ & - \\
\hline Respondent's level of satisfaction with health impacts of tap water (instrumented) & - & $0.150 * * *$ \\
\hline Age of respondents & $-0.003 * * *$ & $-0.003 * * *$ \\
\hline $\begin{array}{l}\text { Education } \\
\text { (respondent completed at least one year of education after high school }=1 \text { ) }\end{array}$ & 0.004 & 0.006 \\
\hline $\begin{array}{l}\text { Children } \\
\text { (at least one child under } 5 \text { years old }=1 \text { ) }\end{array}$ & -0.002 & 0.002 \\
\hline $\begin{array}{l}\text { Urban area } \\
(\text { respondent lives in a major town/city or in a suburban area }=1 \text { ) }\end{array}$ & $0.069 * *$ & $0.081 * * *$ \\
\hline Level of trust about the environmental impacts of products & $-0.027 * * *$ & $-0.034 * * *$ \\
\hline Score on "environmental concern" index & -0.015 & $-0.017 *$ \\
\hline Respondent belongs to the 'environmentally motivated' class (ref) & - & - \\
\hline Respondent belongs to the 'technological optimists' class & 0.014 & 0.014 \\
\hline Respondent belongs to the 'environmental sceptics' class & $-0.067 * *$ & $-0.059 *$ \\
\hline constant & $0.513 * * *$ & $0.483 * * *$ \\
\hline
\end{tabular}

Number of observations

$11,682 \quad 11,145$

Wald test of exogeneity

$\operatorname{chi} 2(1)=0.37 \quad \operatorname{chi} 2(1)=0.06$ $\mathrm{p}$-value $=0.5451 \quad \mathrm{p}$-value $=0.8091$

First-stage regressions
Respondent's level of satisfaction with respect to water quality

Satisfaction with Satisfaction with

Age of respondents

$0.608 * * * \quad 0.589 * * *$

Education

$0.011 * * * \quad 0.014 * * *$

(respondent completed at least one year of education after high school $=1$ )

$0.103^{*} \quad 0.115^{* *}$

Level of trust about the environmental impacts of products

$0.153 * * * \quad 0.197 * * *$

Urban area

(respondent lives in a major town/city or in a suburban area $=1$ )

$0.135 * * * \quad 0.088^{*}$

Score on "environmental concern" index

$0.130 * * * \quad 0.106 * * *$

Children (at least one child under 5 years old $=1$ )

$-0.097$

$-0.042$

Respondent belongs to the 'environmentally motivated' class (ref)

Respondent belongs to the 'technological optimists' class

0.004

0.017

Respondent belongs to the 'environmental sceptics' class

$-0.031$

$-0.013$

constant

$4.253 * * *$

$4.168 * * *$

Number of observations

11,682

11,145

Adj R-squared

0.1880

0.1937

${ }^{* * *} p<0.01,{ }^{* *} p<0.05,{ }^{*} p<0.1$. Country-level fixed effects and regression constant included in estimation but not shown in table. 